This item was submitted to Loughborough's Research Repository by the author.

Items in Figshare are protected by copyright, with all rights reserved, unless otherwise indicated.

\title{
Removal of benzoylecgonine from water matrices through UV254/H2O2 process: Reaction kinetic modeling, ecotoxicity and genotoxicity assessment
}

PLEASE CITE THE PUBLISHED VERSION

http://dx.doi.org/10.1016/j.jhazmat.2016.07.034

\section{PUBLISHER}

(C) Elsevier

VERSION

AM (Accepted Manuscript)

\section{PUBLISHER STATEMENT}

This work is made available according to the conditions of the Creative Commons Attribution-NonCommercialNoDerivatives 4.0 International (CC BY-NC-ND 4.0) licence. Full details of this licence are available at: https://creativecommons.org/licenses/by-nc-nd/4.0/

\section{LICENCE}

CC BY-NC-ND 4.0

\section{REPOSITORY RECORD}

Spasiano, Danilo, Danilo Russo, Marianna Vaccaro, A. Siciliano, Raffaele Marotta, M. Guida, Nuno M. Reis, Gianluca Li Puma, and Roberto Andreozzi. 2016. "Removal of Benzoylecgonine from Water Matrices Through UV254/H2O2 Process: Reaction Kinetic Modeling, Ecotoxicity and Genotoxicity Assessment”. figshare. https://hdl.handle.net/2134/22962. 
Hazardous Materials

Elsevier Editorial System(tm) for Journal of

Manuscript Draft

Manuscript Number: HAZMAT-D-16-02632R1

Title: Removal of benzoylecgonine from water matrices through UV254/H202 process: reaction kinetic modeling, ecotoxicity and genotoxicity assessment

Article Type: Research Paper

Keywords: benzoylecgonine, illicit drugs, AOP, kinetic modeling, ecotoxicological assessment

Corresponding Author: Mr. Danilo Spasiano, PhD

Corresponding Author's Institution: Politecnico di Bari

First Author: Danilo Spasiano, PhD

Order of Authors: Danilo Spasiano, PhD; Danilo Russo; Marianna Vaccaro; Antonietta Siciliano; Raffaele Marotta; Marco Guida; Nuno M Reis; Gianluca Li Puma; Roberto Andreozzi

Abstract: Benzoylecgonine (BE), the main cocaine metabolite, has been detected in numerous surface water and treatment plants effluents in Europe and there is urgent need for effective treatment methods. In this study, the removal of BE by the UV254/H2O2 process from different water matrices was investigated. By means of competition kinetics method, the kinetic constant of reaction between $B E$ and the photogenerated hydroxyl radicals $(* \mathrm{OH})$ was estimated resulting in $\mathrm{kOH} / \mathrm{BE}=5.13 * 109 \mathrm{M}-1{ }^{*} \mathrm{~s}-1$. $\mathrm{BY}-$ products and water matrices scavengers effects were estimated by numerical modeling of the reaction kinetics for the UV254/H2O2 process and validated in an innovative microcapillary film (MCF) array photoreactor and in a conventional batch photoreactor. The ecotoxicity of the water before and after treatment was evaluated with four organisms Raphidocelis subcapitata, Daphnia magna, Caenorhabditis elegans, and Vicia faba. The results provided evidence that BE and its transformation by-products do not have significant adverse effects on $\mathrm{R}$. subcapitata, while D. magna underwent an increase of lipid droplets. C. elegans was the most sensitive to BE and its by-products. Furthermore, a genotoxicity assay, using $V$. faba, showed cytogenic damages during the cell mitosis of primary roots. 
DICATECh - Politecnico di Bari

Via Orabona, 4, 70125, Bari, Italy

Prof. Gerasimos Lyberatos

Editor of Journal of Hazardous Materials

Dear Prof. Lyberatos

please find enclosed a copy of the original manuscript:

"Removal of benzoylecgonine from water matrices through $\mathrm{UV}_{254} / \mathrm{H}_{2} \mathrm{O}_{2}$ process: reaction kinetic modeling, ecotoxicity and genotoxicity assessment"

by Danilo Spasiano, Danilo Russo, Marianna Vaccaro, Antonietta Siciliano, Raffaele Marotta, Marco Guida, Nuno Reis, Gianluca Li Puma, and Roberto Andreozzi.

Number of words: 4998.

In this study, we present a kinetic model of the $\mathrm{UV}_{254} / \mathrm{H}_{2} \mathrm{O}_{2}$ process for the removal of benzoylecgonine from different water matrices (milli-Q water, synthetic wastewater, real wastewater, and real surface water) by means of an innovative microcapillary film (MCF) array photoreactor, which allows very fast experimentation with minimal sample volumes. Benzoylecgonine is the major metabolite of cocaine and an emerging contaminant often detected in wastewater treatment plants, effluents and surface waters in higher concentrations than its parent compound. The MCF is an effective experimental tool to study oxidative removal of highly priced, uncommon, or regulated substances such as BE. Competition kinetics in the presence of benzoic acid was used to determine the second-order rate constant $\left(\mathrm{k}_{\mathrm{OH} / \mathrm{BE}}\right)$ for the reaction of $\mathrm{BE}$ with ${ }^{\circ} \mathrm{OH}$. The effect of by-products and water matrices scavengers was estimated by numerical modeling of the reaction kinetics for the $\mathrm{UV}_{254} / \mathrm{H}_{2} \mathrm{O}_{2}$ process in the MCF array photoreactor dissolving $\mathrm{BE}$ in milli-Q water, synthetic wastewater, real wastewater, and real surface water. Ecotoxicological bioassays with $R$. subcapitata, D. magna and $C$. elegans were further used to provide information 
for environmental health and to investigate the effects of BE before and after the proposed treatment. These biomarkers were selected since have not been used in BE toxicity tests. Several endpoints were monitored on terrestrial and aquatic organisms to expand the range of effect expression due to differences in species sensitivity and exposure. Furthermore, the potential genotoxicity of $\mathrm{BE}$ and its by-products was investigated by means of the count of micronucleus observed in $V$. faba roots.

We believe that this topic is of high interest to the readership of Journal of Hazardous Materials, since it deals with the removal of a hazardous contaminant of emerging concern widely found in wastewater effluents and surface waters.

This is an original manuscript not submitted elsewhere. All the authors confirm that the present manuscript has been prepared in compliance with the Ethics in Publishing Policy as described in the Guide for Authors of Journal of Hazardous Materials.

We look forward to receiving your editorial response in due course.

Yours sincerely

Danilo Spasiano, $\mathrm{PhD}$ 
Dear Prof. Gerasimos Lyberatos, please find enclosed a copy of the paper "Removal of benzoylecgonine from water matrices through $\mathrm{UV}_{254} / \mathrm{H}_{2} \mathrm{O}_{2}$ process: reaction kinetic modeling, ecotoxicity and genotoxicity assessment" by Danilo Spasiano, Danilo Russo, Marianna Vaccaro, Antonietta Siciliano, Raffaele Marotta, Marco Guida, Nuno M Reis, Gianluca Li Puma and Roberto Andreozzi (Manuscript No. HAZMAT-D-1602632) which has been revised according to the Referees' minor revisions (all the corrections and new insertions have been printed in red bold typefaces).

We thank the Referees for their valuable suggestions that helped us to ameliorate the text and mostly you for the assistance and cooperation.

The Authors

\section{Reviewer \#1:}

The study determines kinetics on removal/degradation of $\mathrm{BE}$, a main cocaine metabolite, by $\mathrm{UV} / \mathrm{H}_{2} \mathrm{O}_{2}$ process. The authors test the process on different water matrices such as wastewater and surface water, as well as evaluate the effect of by-products and scavenging process. At the end, the authors make a preliminary toxicity tests (before and after process) in a batch reactor because of work facilities.

If well the degradation of $\mathrm{BE}$ through $\mathrm{UV} / \mathrm{H}_{2} \mathrm{O}_{2}$ process it has been studied, this manuscript has special emphasis on determine kinetics of the process and, specially, on kinetics by-products scavengers, which is an interesting contribution. Moreover, the use of an innovative photoreactor for this purposes makes a remarkable study.

I write below some suggestions for easy understand the whole manuscript, and some little mistakes I founded on it.

- Specific comments by sections:

\section{ABSTRACT:}

It is well write and easy resume of the manuscript. 


\section{HIGHLIGHTS:}

The meanings of the highlights are un-precise; authors should consider improving the highlights with emphasis on results.

Reply: The highlights are completely rearranged in agreement with reviewer's suggestions.

\section{INTRODUCTION:}

- Second Paragraph: Authors explain impact of BE in different aquatic organisms. I think the effect on cat brains is out of the context in this study.

Reply: The paragraph and the relative reference are removed from the manuscript as suggested by the reviewer.

- Fourth paragraph: "Furthermore, the ecotoxicity and genotoxicity of the transformation byproducts of the $\mathrm{UV}_{254} / \mathrm{H}_{2} \mathrm{O}_{2}$ process remains unclear". Some reference?

Reply: The cited sentence is referred to the BE by-products. It has been rearranged with the aim of clarify its meaning. At the Authors knowledge, there are no references about the ecotoxicity and genotoxicity of $\mathrm{BE}$ by-products deriving from $\mathrm{UV}_{254} / \mathrm{H}_{2} \mathrm{O}_{2}$ process. The text (page 3) was revised as follows:

Furthermore, the ecotoxicity and genotoxicity of the BE transformation by-products generated through the $\mathrm{UV}_{254} / \mathrm{H}_{2} \mathrm{O}_{2}$ process have not been reported.

\section{METHODS:}

-Analytical Methods:

-"Algal densities were determined by an indirect procedure using a spectrophotometer..." At which absorbance? Did you relate them with concentration measure? I guess you obtained a calibration curve, so will be good if you state at least the correlation between absorbance and concentration measure.

Reply: The text on page 5 was revised as follows:

Algal densities were followed by optical density measurements at $670 \mathrm{~nm}\left(\mathrm{OD}_{670 \mathrm{~nm}}\right)$ using a spectrophotometer (Hach Lange DR5000) and a $5 \mathrm{~cm}$ cuvette $\left(\mathrm{OD}_{670 \mathrm{~nm}}=1.69 \cdot 10^{6}\right.$ algae $\cdot \mathrm{ml}^{-1}+$ 105857; $\mathrm{R}^{2}=0.99$ ).

- Maybe a little explain about how relate $\mathrm{H} 2 \mathrm{O} 2$ actinometry with fluence/dose on UV reactor will be helpful. 
Reply: The experimental procedure for the determination of photonic flux at $254 \mathrm{~nm}$ emitted by low-pressure mercury vapor lamp is well described in the references [41,42] of the manuscript. Furthermore, a complete description about the estimation of $\mathrm{UV}_{254}$ photon flux emitted by the lamp coupled with the MCF used in this experimental campaign was already reported in a previous paper we recently published and cited in this manuscript as the $21^{\text {st }}$ reference (see sections 3.2 and 3.3). We consider further explanation in this paper as redundant.

- I think authors should write a little paragraph about the initial concentration of $\mathrm{H}_{2} \mathrm{O}_{2}$, how to determine it, and if they remove the residual peroxide for post-analysis in the way residual $\mathrm{H}_{2} \mathrm{O}_{2}$ can still be active. It is clear for V. faba seeds, but what about the rest?

I see on results that there is no degradation of it during the process, so $\mathrm{H}_{2} \mathrm{O}_{2}$ should be removed before post-treatments analysis.

Reply: We are grateful to the referee for these valuable suggestions. $\mathrm{H}_{2} \mathrm{O}_{2}$ concentrations were monitored by means of HPLC analysis (see section 2.2.). As reported in section 2.3.4. "Negative tests were carried out on aqueous solutions containing $6.3 \mathrm{mM}$ of hydrogen peroxide and $80 \mu \mathrm{L} \cdot \mathrm{L}^{-1}$ of catalase (used to destroy the residual hydrogen peroxide), to verify that the mixture did not exert negative effects on the target organisms." On the other hand, for the position of the sentence it seems that this blank tests were carried out only for the V. faba seed and not for all the tested living organisms. Moreover, we omitted to report in the paper that the same amount of catalase from Micrococcus lysodeikticuswas was also rapidly added to the fresh samples at the three different treatment times. In fact, our goal was to estimate the toxic effect of BE and its by-products only and not that of the mixture of these compounds with $6.3 \mathrm{mM}$ of $\mathrm{H}_{2} \mathrm{O}_{2}$. For this purpose, the sentence we cited was moved from its initial position and modified in order to overcome all misunderstandings highlighted by the referee (second paragraph of section 2.3.4) now reads as follows:

$80 \mu \mathrm{L} \cdot \mathrm{L}^{-1}$ of catalase (used to destroy the residual hydrogen peroxide) were diluted into the fresh samples collected from the batch reactor at the three different reaction times with the aim of neglecting the toxic effect of $\mathrm{H}_{2} \mathrm{O}_{2}$ present into the solutions at the concentration of $6.3 \mathrm{mM}$. Negative tests were carried out on aqueous solutions containing $6.3 \mathrm{mM}$ of hydrogen peroxide and $80 \mu \mathrm{L} \cdot \mathrm{L}-1$ of catalase (used to destroy the residual hydrogen peroxide), to verify that the mixture did not exert negative effects on the four target organisms.

\section{RESULTS AND DISCUSSION}

-Table 1 is a little bit confuse: Each column is a different run? Please, specify which each column means. 
Reply: Thank you for the precious suggestion. The table has been modified in agreement with the referee' suggestion.

-Explanation of Eq. 18: "k $\mathrm{HO}$ /BP was thee only unknown parameter". "The" instead of "thee" Reply: It has been corrected.

- "The $\mathrm{UV}_{25} / \mathrm{H}_{2} \mathrm{O}_{2} / \mathrm{BE}$ reaction kinetics model was validated by predicting the results of four additional runs carried out at a different photon flux (Table 2, runs 1s-4s)". Table 2 is actually table 3.

Reply: It has been corrected.

- "The standard deviations calculated for both $\mathrm{BE}$ and $\mathrm{H}_{2} \mathrm{O}_{2}$ (Table 3) were found to be below $1.06 \% "$. It is below $1.35 \%$ according to values of table 3 .

Reply: The sentence the referee highlighted was related only to the runs used in the simulation mode: that explains the reason why we reported the $1.06 \%$ as the maximum standard deviation value. On the other hand, in agreement with the reviewer suggestion, it is more correct to refer this sentence to all the experimental runs used for both the optimization and simulation mode. At this purpose, we substitutes the $1.06 \%$ with $1.41 \%$ (standard deviation value on BE, run 6 , table 3 ) as the maximum found standard deviation value.

- On figure 4 does not appear the predicted line for $\mathrm{H}_{2} \mathrm{O}_{2}$, please plot it.

Reply: Done.

- "...MCF has been observed [22] and Following the same optimization methodology reported earlier". "f" instead of "F" on Following.

Reply: Done.

\section{CONCLUSIONS}

Conclusions are according to the experimental results. The authors explain the necessity of further investigations on toxicity field, which is a realistic requirement. 


\section{REFERENCES}

References are up to date. I suggest some fresh references (year 2016) about $\mathrm{UV} / \mathrm{H}_{2} \mathrm{O}_{2}$ process application and optimization and BE genotoxicity:

-Parolini, M., Magni, S., Castiglioni, S., Binelli, A. (2016). Genotoxic effects induced by the exposure to an environmental mixture of illicit drugs to the zebra mussel Ecotoxicology and Environmental Safety, 132, pp. 26-30. http://doi.org/10.1016/j.ecoenv.2016.05.022

-Moreno-Andrés, J., Romero-Martínez, L., Acevedo-Merino, A., \&Nebot, E. (2016). Determining disinfection efficiency on E. faecalis in saltwater by photolysis of $\mathrm{H}_{2} \mathrm{O}_{2}$ : Implications for ballast water treatment. Chemical Engineering Journal, 283, 1339 - 1348. http://doi.org/10.1016/j.cej.2015.08.079

Reply: We appreciated the reviewer suggestion. These new papers have been cited into the manuscript as the $13^{\text {th }}$ and $24^{\text {th }}$ reference respectively. Moreover, considering the referee' comments, we also changed the $58^{\text {th }}$ reference with the following updated review: J. Schmidhuber, Deep learning in neural networks: An overview, Neural Networks 61 (2015) 85-117.

\section{Reviewer \#2}

The manuscript submitted by Spasiano et al. is a novel piece of work which includes unpublished data related to benzoylecgonine kinetics. This work shows a deep kinetic study with a thorough statistical analysis and a modelling approach. I recommend its publication in Journal of Hazardous Materials, provided some minor issues are addressed:

- The Introduction would be enriched if some background around the state of the art on BE ecotoxicity is included

Reply: As also suggested by Reviewer \#1, we added an additional reference regarding the BE genotoxic effect on zebra mussel (Parolini et al., 2016), reference $13^{\text {th }}$.

- How can the toxicity tests under taken in this work be extrapolated to real situations, with lower pollutant concentrations? How do the Authors' findings signify? Can the evolution of toxicity during degradation be extrapolated to lower pollutant concentrations? Please discuss in the text 
Reply: E.E. Kenaga [70] summarized 125 acute chronic ratio (ACR) values for 84 chemicals 11 species of aquatic organisms. This parameter, expressed as the ratio among the acute EC50 and the chronic toxicity (maximum acceptable toxicant concentration, MATC), was find to be in the range 1.0-1.8 $10^{4}$. Considering an ACR equal to $10^{3}$ and the EC50 of BE on nematodes evaluated in this work $(0.6 \mathrm{ppm})$, a chronic toxic effect could be observed on nematodes at the BE concentration equal to $0.6 \mathrm{ppb}$. The predicted MATC value is in agreement with the results previously reported [13-15] regarding the negative effect of $\mathrm{BE}$ contaminated water solutions (0.5 and $1.0 \mathrm{ppb})$ on Dreissena polymorpha. Moreover, the ecotoxicity and genotoxicity tests carried out with the sample withdrawn at tf suggest, considering the same ACR value, that it is possible that the by-products, deriving by the $\mathrm{UV}_{254} / \mathrm{H}_{2} \mathrm{O}_{2}$, treatment of a solution containing $\mathrm{BE}$ at the concentration of $1 \mathrm{ppb}$, could exert a negative chronic effect on living organisms.

All these considerations could be obviously validated through dedicated chronic tests, but the results regarding the acute toxicity of $\mathrm{BE}$ and its by-products on $C$. elegans and $V$. faba, suggest that chronic negative effects could be observed on living organisms subjected to the $\mathrm{BE}$ concentrations founded in STP effluents and surface waters.

All these consideration were added at the end of the section 3.3, as follows:

In a previous paper [70], 125 acute chronic ratio (ACR) values for 84 chemicals and 11 species of aquatic organisms were summarized. The ACR, expressed by the ratio of the acute EC50 and the chronic toxicity (maximum acceptable toxicant concentration, MATC), was found to be in the range 1.0-1.8 104. Considering an ACR equal to 103 and the EC50 of BE on C. elegans evaluated in this work $(0.6 \mathrm{ppm})$, a chronic toxic effect could be observed on nematodes at the BE concentration equal to $0.6 \mathrm{ppb}$. In particular, the predicted MATC value is in agreement with the results previously reported [13-15] regarding the negative effect of BE contaminated water solutions $(0.5$ and $1.0 \mathrm{ppb}$ ) on Dreissena polymorpha. Moreover, the ecotoxicity and genotoxicity tests carried out with the sample withdrawn at tf suggest, considering the same ACR value, that it is possible that the by-products, deriving by the UV254/H2O2, treatment of a solution containing $\mathrm{BE}$ at the concentration of $1 \mathrm{ppb}$, could exert a negative chronic effect on living organisms.

All these considerations could be certainly validated through dedicated chronic tests, but the results regarding the acute toxicity of $\mathrm{BE}$ and its by-products on $\mathrm{C}$. elegans and $\mathrm{V}$. faba, suggest that chronic negative effects could also be observed on living organisms subjected to the $\mathrm{BE}$ concentrations founded in STP effluents and surface waters.

- Please add the limit of detection of the HPLC method and retention times

Reply: We have added this information on Section 2.2 as follows: 
The retention times for $\mathrm{H}_{2} \mathrm{O}_{2}, \mathrm{BE}$, and BA were 4.9, 13.8 and 17.1 min, respectively. Moreover, $\mathrm{H}_{2} \mathrm{O}_{2}, \mathrm{BE}$, and $\mathrm{BA}$ concentrations down to $0.01 \mathrm{mM}, 1.2 \cdot 10^{-4} \mathrm{mM}$ and $2.08 \cdot 10^{-3} \mathrm{mM}$ were successfully measured.

- What is the MCF reactor volume?

Reply: The MCF reactor (microcapillary film array photoreactor, see introduction) is a tubular continuous flow reactor so that its volume is strictly dependent on the length exposed to the UV radiation (only this can be properly defined as "reactor"). That is, for this experimental campaign, a volume ranging from 0 to $0.045 \mathrm{~mL}$. If you are asking for the whole volume of the microcapillary film strip adopted, this is about $0.66 \mathrm{~mL}$, for a length of about $2 \mathrm{~m}$. The geometric properties among with the fluid dynamics of the reactor are reported in a previous paper we recently published and cited in this manuscript as the $21^{\text {st }}$ reference. The information on the reactor volume was added in the manuscript as follows:

The MCF reactor volume exposed to UV irradiation varied according to the space time between 0 and $0.045 \mathrm{ml}$. 

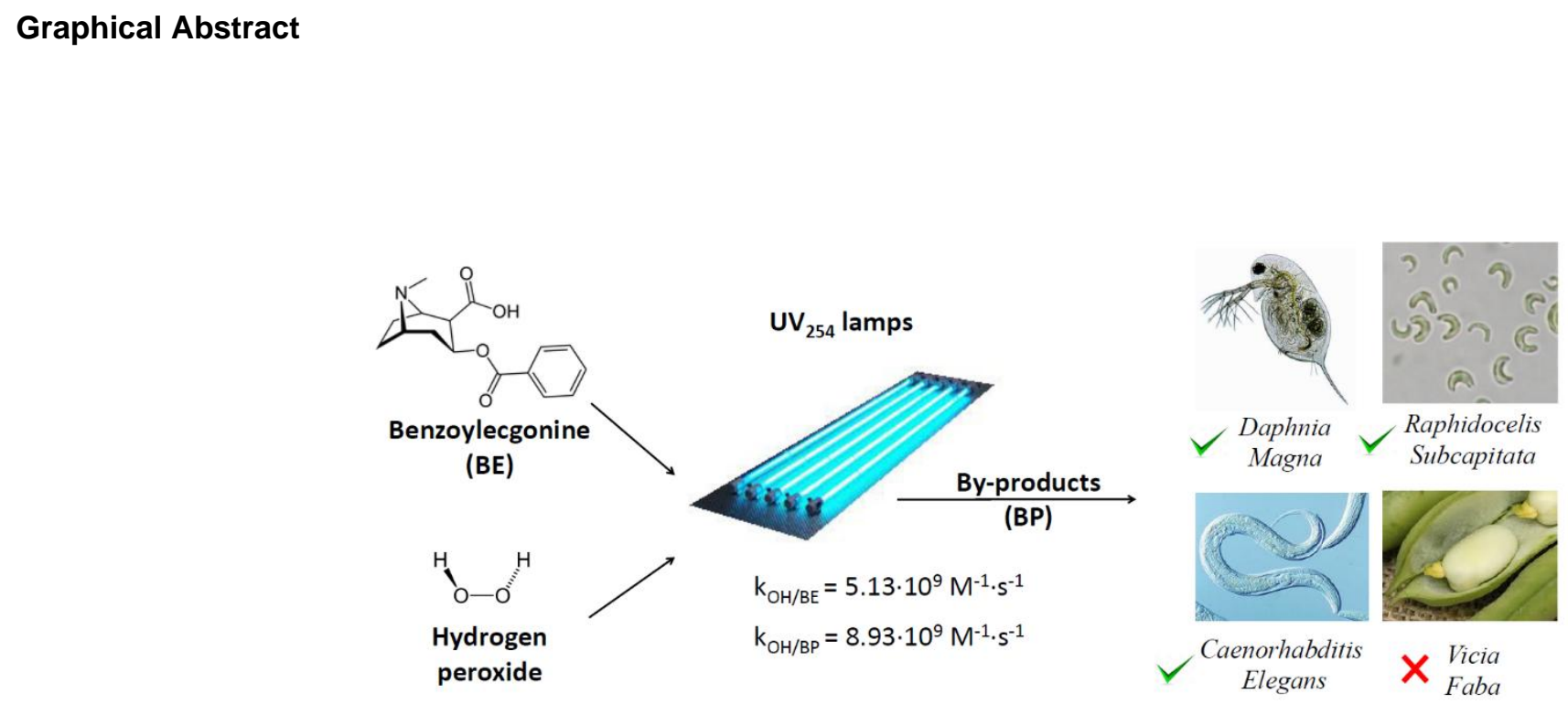

\section{Graphical Abstract}




\begin{abstract}
Benzoylecgonine (BE), the main cocaine metabolite, has been detected in numerous surface water and treatment plants effluents in Europe and there is urgent need for effective treatment methods. In this study, the removal of $\mathrm{BE}$ by the $\mathrm{UV}_{254} / \mathrm{H}_{2} \mathrm{O}_{2}$ process from different water matrices was investigated. By means of competition kinetics method, the kinetic constant of reaction between $\mathrm{BE}$ and the photogenerated hydroxyl radicals $\left({ }^{\circ} \mathrm{OH}\right)$ was estimated resulting in $\mathrm{k}_{\mathrm{OH} / \mathrm{BE}}=5.13 \cdot 10^{9} \mathrm{M}^{-1} \cdot \mathrm{s}^{-}$ ${ }^{1}$. By-products and water matrices scavengers effects were estimated by numerical modeling of the reaction kinetics for the $\mathrm{UV}_{254} / \mathrm{H}_{2} \mathrm{O}_{2}$ process and validated in an innovative microcapillary film (MCF) array photoreactor and in a conventional batch photoreactor. The ecotoxicity of the water before and after treatment was evaluated with four organisms Raphidocelis subcapitata, Daphnia magna, Caenorhabditis elegans, and Vicia faba. The results provided evidence that BE and its transformation by-products do not have significant adverse effects on $R$. subcapitata, while $D$. magna underwent an increase of lipid droplets. C. elegans was the most sensitive to BE and its byproducts. Furthermore, a genotoxicity assay, using $V$. faba, showed cytogenic damages during the cell mitosis of primary roots.
\end{abstract}




\section{Highlights}

- $\mathrm{UV} / \mathrm{H}_{2} \mathrm{O}_{2}$ oxidation process is effective for $\mathrm{BE}$ removal from aqueous matrices

- MCF photoreactor technology is a valid and useful tool in AOPs studies

- The kinetic constants of HO radicals attack to BE and its by-products are estimated

- $\mathrm{BE}$ removal through $\mathrm{UV} / \mathrm{H}_{2} \mathrm{O}_{2}$ process is modeled in different aqueous matrices

- Genotoxicity tests suggest the risk of long term effects of $\mathrm{BE}$ by-products 


\title{
Removal of benzoylecgonine from water matrices through $\mathrm{UV}_{254} / \mathrm{H}_{2} \mathrm{O}_{2}$ process: reaction kinetic modeling, ecotoxicity and genotoxicity assessment
}

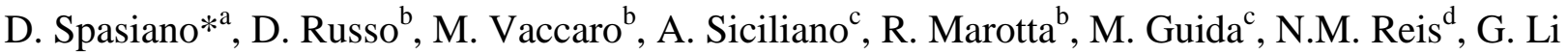
Puma*d $^{\mathrm{d}}$, R. Andreozzi ${ }^{\mathrm{b}}$

${ }^{\text {a }}$ Dipartimento di Ingegneria Civile, Ambientale, del Territorio, Edile e di Chimica, Politecnico di Bari, Via E. Orabona, 4 - 70125 - Bari, Italia.

${ }^{\mathrm{b}}$ Dipartimento di Ingegneria Chimica, dei Materiali e della Produzione Industriale, Università di Napoli Federico II, p.le V. Tecchio, 80 - 80125 - Napoli, Italia.

${ }^{\mathrm{c}}$ Dipartimento di Biologia, Università di Napoli Federico II, Via Cinthia - 80126 - Napoli, Italia.

${ }^{\mathrm{d}}$ Environmental Nanocatalysis \& Photoreaction Engineering Department of Chemical Engineering, Loughborough University, Loughborough LE11 3TU, UK.

Keywords: benzoylecgonine, illicit drugs, AOP, kinetic modeling, ecotoxicological assessment

\begin{abstract}
Benzoylecgonine (BE), the main cocaine metabolite, has been detected in numerous surface water and treatment plants effluents in Europe and there is urgent need for effective treatment methods. In this study, the removal of $\mathrm{BE}$ by the $\mathrm{UV}_{254} / \mathrm{H}_{2} \mathrm{O}_{2}$ process from different water matrices was investigated. By means of competition kinetics method, the kinetic constant of reaction between $\mathrm{BE}$ and the photogenerated hydroxyl radicals $\left({ }^{\circ} \mathrm{OH}\right)$ was estimated resulting in $\mathrm{k}_{\mathrm{OH} / \mathrm{BE}}=5.13 \cdot 10^{9} \mathrm{M}^{-1} \cdot \mathrm{s}^{-}$ 1. By-products and water matrices scavengers effects were estimated by numerical modeling of the reaction kinetics for the $\mathrm{UV}_{254} / \mathrm{H}_{2} \mathrm{O}_{2}$ process and validated in an innovative microcapillary film (MCF) array photoreactor and in a conventional batch photoreactor. The ecotoxicity of the water before and after treatment was evaluated with four organisms Raphidocelis subcapitata, Daphnia
\end{abstract}


magna, Caenorhabditis elegans, and Vicia faba. The results provided evidence that BE and its transformation by-products do not have significant adverse effects on $R$. subcapitata, while $D$. magna underwent an increase of lipid droplets. C. elegans was the most sensitive to BE and its byproducts. Furthermore, a genotoxicity assay, using $V$. faba, showed cytogenic damages during the cell mitosis of primary roots.

\section{Introduction}

$\mathrm{BE}$ is a contaminant of emerging concern deriving from the consumption of cocaine, one of the most widely used illicit drugs [1]. The human metabolism of cocaine is dominated by hydrolytic ester cleavage resulting in urine metabolites consisting mostly of BE (45\%), ecgonine methyl ester (40\%), and a residue of unchanged cocaine (1-9\%) [2]. Consequently, BE represents the primary cocaine metabolite and it is detected in almost all surface water (SurW) and sewage treatment plants (STP) effluents in Europe always at levels higher than cocaine $[3,4]$. Although the removal of BE in conventional STP is typically $80 \%[5,6]$, the effluent concentrations is in the range $0.1-3275 \mathrm{ng} \cdot \mathrm{L}^{-1}$ $[7,8] . \mathrm{BE}$ in SurW ranges between $0.3-530 \mathrm{ng} \cdot \mathrm{L}^{-1}[9-11]$ and in river sediments is reported as $1.0 \mathrm{ng}$ $\mathrm{g}^{-1}[12]$.

The exposure of freshwater mussel, Dreissena polymorpha, to BE contaminated water solutions (0.5 and $1.0 \mathrm{ppb}$ ), yielded a 3.5-fold increase in oxidative stress and increased or inhibited antioxidant and detoxifying enzymes activity depending on BE levels and exposure time [13-15]. Significant lipids peroxidation and protein carbonylation, DNA damage, and cellular apoptotic death were observed in experiments carried out up to 14 days [16]. Another study showed the negative effect of BE on fishes and plants [17].

The $\mathrm{UV}_{254} / \mathrm{H}_{2} \mathrm{O}_{2}$ is an emerging STP tertiary treatment process, which is increasingly being used for water reuse in public works and in agriculture [18-20]. In previous studies [21,22] we have investigated the BE removal with both $\mathrm{UV}_{254}$ and $\mathrm{UV}_{254} / \mathrm{H}_{2} \mathrm{O}_{2}$ using an innovative microcapillary film (MCF) array photoreactor, which allowed extremely rapid experimentation with minimal 
sample volumes. The feasibility of BE removal by direct photolysis $\left(\mathrm{UV}_{254}\right)$ in STP during a conventional water disinfection treatment is questionable due to the low molar adsorption coefficient and quantum yield [21]. However, BE removal in STP is a promising proposition using the $\mathrm{UV}_{254} / \mathrm{H}_{2} \mathrm{O}_{2}$ process, as we determined much faster $\mathrm{BE}$ oxidation in different water matrices: milliQ water, synthetic wastewater (SWW), real wastewaters (RWW), and SurW [22]. Other studies have demonstrated that Fenton, Fenton-like, and potassium ferrate treatment are also effective methods for BE removal in STP effluents [23] although their practical implementation can be problematic.

In this study, we therefore focused on the $\mathrm{UV}_{254} / \mathrm{H}_{2} \mathrm{O}_{2}$ process as a potential tertiary treatment of STP effluents [24-31] since it appears of more feasible implementation.

In the $\mathrm{UV}_{254} / \mathrm{H}_{2} \mathrm{O}_{2}$ process the homolytic cleavage of $\mathrm{H}_{2} \mathrm{O}_{2}$ leads to the formation of ${ }^{\circ} \mathrm{OH}$ radicals (1) that unselectively attack dissolved organic substances such as BE (2) [32]:

$$
\begin{aligned}
\mathrm{H}_{2} \mathrm{O}_{2} & \stackrel{\mathrm{hv}}{\rightarrow} 2 \cdot \mathrm{OH} \\
\cdot \mathrm{OH} & +\mathrm{BE} \stackrel{\mathrm{k}_{\mathrm{OH} / \mathrm{s}}}{\longrightarrow} \mathrm{By}-\text { products }
\end{aligned}
$$

However, the second-order rate constant $\left(\mathrm{k}_{\mathrm{OH} / \mathrm{BE}}\right)$ for the reaction of $\mathrm{BE}$ with ${ }^{\circ} \mathrm{OH}$ is unknown. Furthermore, the ecotoxicity and genotoxicity of the BE transformation by-products generated through the $\mathrm{UV}_{254} / \mathrm{H}_{2} \mathrm{O}_{2}$ process have not been reported.

In this study, competition kinetics in the presence of benzoic acid (BA) [33,34], was used to determine the second-order rate constant $\left(\mathrm{k}_{\mathrm{OH} / \mathrm{BE}}\right)$ for the reaction of $\mathrm{BE}$ with ${ }^{\circ} \mathrm{OH}$, which was evaluated in the MCF array photoreactor and validated in a batch photoreactor. The effect of byproducts and water matrices scavengers was estimated by numerical modeling of the reaction kinetics for the $\mathrm{UV}_{254} / \mathrm{H}_{2} \mathrm{O}_{2}$ process in the MCF array photoreactor dissolving BE in milli-Q water, SWW, RWW, and SurW. Ecotoxicological bioassays with R. subcapitata, D. magna and C. elegans were further used to provide information for environmental health and to investigate the effects of BE before and after the proposed treatment. Several endpoints were monitored on terrestrial and 
aquatic organisms to expand the range of effect expression due to differences in species sensitivity and exposure. Furthermore, the potential genotoxicity of BE and its by-products was investigated by means of the count of micronuclei observed in $V$. faba roots.

This study was based on the "effect-driven approach" [35] in which a parent compound is undergoing degradation and is analyzed with eco-bioassays to follow the toxicity evolution during a transformation process.

Indeed, it was chosen an initial concentration of BE higher than usually found in effluents or SurW [7-12] to better assess ecotoxicological effects of by-products solutions, as reported in previous studies [36-38]. Furthermore, such high concentrations are not of limited relevance because they are suitable to determine the median effective concentration (EC50), an indicator of by-products toxicity and the time onset of the effects.

The investigation on the relative toxicities of $\mathrm{BE}$ and its by-products is relevant to future discussions regarding the treatment, control and fate of $\mathrm{BE}$ and BE-derivatives in the environment.

\section{Materials and methods}

\subsection{Materials}

Hydrogen peroxide $(30 \% \mathrm{v} / \mathrm{v})$, benzoylecgonine $(\geq 99 \% \mathrm{w} / \mathrm{w})$, acetonitrile $(\geq 99.9 \% \mathrm{v} / \mathrm{v})$, formic acid $(\geq 95 \% \mathrm{v} / \mathrm{v})$, benzoic acid $(\geq 99.5 \% \mathrm{w} / \mathrm{w})$, catalase from Micrococcus lysodeikticus were purchased from Sigma-Aldrich. Milli-Q water (18 M $\Omega$ resistivity) was prepared with a Millipore Elix water purification system.

In agreement with the OECD guidelines [36], SWW was prepared with peptone (32 ppm), meat extract (22 ppm), urea (6 ppm), $\mathrm{K}_{2} \mathrm{HPO}_{4}$ (28 ppm), $\mathrm{CaCl}_{2} \cdot \mathrm{H}_{2} \mathrm{O}$ (4 ppm), $\mathrm{NaCl}(7 \mathrm{ppm})$ and $\mathrm{Mg}_{2} \mathrm{SO}_{4}$ $(0.6 \mathrm{ppm})$ in milli-Q water. These substances were from Sigma-Aldrich and were used as received. RWW was sampled from the Severn Trent Sewage Water Treatment Plant of Festival Drive, Loughborough, Leicestershire (UK). SurW was collected from the Grand Union Canal in the same 
area. RWW and SurW samples were filtered through Whatman nylon filters $(0.45 \mu \mathrm{m})$ to avoid clogging of the MCF and of the high performance liquid chromatography (HPLC).

For toxicity assessment, reference toxicants (potassium dichromate, cupric chloride, maleic hydrazide) and salts for the preparation of artificial freshwater $\left(\mathrm{CaCl}_{2} \cdot 2 \mathrm{H}_{2} \mathrm{O}, \mathrm{MgSO}_{4} \cdot 7 \mathrm{H}_{2} \mathrm{O}, \mathrm{KCl}\right.$, $\mathrm{NaHCO}_{3}, \mathrm{NaNO}_{3}, \mathrm{NH}_{4} \mathrm{Cl}, \mathrm{MgCl}_{2} \cdot 6\left(\mathrm{H}_{2} \mathrm{O}\right), \mathrm{K}_{2} \mathrm{HPO}_{4}, \mathrm{KH}_{2} \mathrm{PO}_{4}, \mathrm{FeCl}_{3} \cdot 6\left(\mathrm{H}_{2} \mathrm{O}\right), \mathrm{Na}_{2} \mathrm{EDTA} \cdot 2\left(\mathrm{H}_{2} \mathrm{O}\right)$ $\left.\mathrm{H}_{3} \mathrm{BO}_{3}, \mathrm{MnCl}_{2} \cdot 4\left(\mathrm{H}_{2} \mathrm{O}\right) \mathrm{ZnCl}_{2}, \mathrm{CoCl}_{2} \cdot 6\left(\mathrm{H}_{2} \mathrm{O}\right), \mathrm{Na}_{2} \mathrm{MoO}_{4} \cdot 2\left(\mathrm{H}_{2} \mathrm{O}\right), \mathrm{CuCl}_{2} \cdot 2\left(\mathrm{H}_{2} \mathrm{O}\right), \mathrm{NaCl}\right)$ were used. All chemicals were analytical grade supplied by Sigma Aldrich. Double distilled water (Microtech) was used to prepare dilution water and treatments.

\subsection{Analytical methods}

Hydrogen peroxide, BE, and benzoic acid were assayed by HPLC (1100 Agilent) equipped with a Gemini C18 (Phenomenex) reverse phase column and a diode array detector $(\lambda=232 \mathrm{~nm})$. The mobile phase was a mixture of formic acid aqueous solution $(25 \mathrm{mM})(\mathrm{A})$ and acetonitrile (B) flowing at $0.6 \mathrm{~mL} \mathrm{~min}^{-1}$ with a gradient $7 \% \mathrm{~B}$ to $28 \% \mathrm{~B}$ in $9 \mathrm{~min}$, then $50 \% \mathrm{~B}$ in $5 \mathrm{~min}$, constant for $2 \mathrm{~min}$, and then to $7 \% \mathrm{~B}$ in $3 \mathrm{~min}$. The retention times for $\mathrm{H}_{2} \mathrm{O}_{2}, \mathrm{BE}$, and $\mathrm{BA}$ were 4.9, 13.8 and

$17.1 \mathrm{~min}$, respectively. Moreover, $\mathrm{H}_{2} \mathrm{O}_{2}, \mathrm{BE}$, and $\mathrm{BA}$ concentrations down to $0.01 \mathrm{mM}, 1.2 \cdot 10^{-4}$ $\mathrm{mM}$ and $2.08 \cdot 10^{-3} \mathrm{mM}$ were successfully measured. The $\mathrm{pH}$ of the reacting solutions and the total organic carbon (TOC) of water samples were measured with an Accumet Basic AB-10 pH-meter and a TOC-5000A TOC analyzer (Shimadzu), respectively.

Crustaceans and nematodes viability were observed with a stereomicroscope (LEICA EZ4-HD) and visualized on a computer. Nuclei and micronuclei were observed through 40x/0.50 objective lenses in a microscope (Nikon, Eclipse E1000) equipped with a digital camera (Nikon, DXM 1200 F) and acquisition software (Nikon ACT1). Algal densities were followed by optical density measurements at $670 \mathrm{~nm}\left(\mathrm{OD}_{670 \mathrm{~mm}}\right)$ using a spectrophotometer (Hach Lange DR5000) and a 5 cm cuvette $\left(O D_{670 \mathrm{~nm}}=1.69 \cdot 10^{6} \operatorname{algae} \cdot \mathrm{ml}^{-1}+105857 ; \mathrm{R}^{2}=0.99\right)$. 


\subsection{Experimental apparatus and procedures}

\subsubsection{MCF photoreactor}

The water matrices (milli-Q, SWW, RWW, and SurW) were spiked with BE and $\mathrm{H}_{2} \mathrm{O}_{2}$. The concentrations of BE $(0.6-18.5 \mathrm{ppm})$ were higher than those found in RWW and SurW $[3,4,7,8]$ to allow a more precise evaluation of the kinetic parameters. $\mathrm{BE}$ and $\mathrm{H}_{2} \mathrm{O}_{2}$ under dark conditions did not react. $\mathrm{BA}(\mathrm{BA}: \mathrm{BE}$ molar ratio $=2.5)$ was added in the runs performed to determine $\mathrm{k}_{\mathrm{OH} / \mathrm{BE}}$ by competition kinetics.

The $\mathrm{UV}_{254} / \mathrm{H}_{2} \mathrm{O}_{2} \mathrm{BE}$ oxidation kinetics were determined in a MCF array photoreactor (Figure 1a) containing 10 microcapillaries with a mean hydraulic diameter (D) of $194 \mu \mathrm{m}$. The description and validation of the MCF array photoreactor has been reported elsewhere [21,40]. The microcapillaries were coiled around a UV monochromatic lamp (Germicidal G8T5, 8W) emitting at $253.7 \mathrm{~nm}$. Segments not coiled were kept in the dark with aluminum foil. Experiments were performed in continuous flow through the reactor at different space times (i.e., the reaction time) with capillaries of different length exposed to the $\mathrm{UV}_{254}$ lamp. The fluid velocity in the capillaries was $5.56 \cdot 10^{-2}$ $\mathrm{m} \cdot \mathrm{s}^{-1}$ and the MCF flow rate was $1.0 \cdot 10^{-3} 1 \cdot \mathrm{min}^{-1}$. The MCF reactor volume exposed to UV irradiation varied according to the space time between 0 and $0.045 \mathrm{ml}$. Samples were collected from the feed and at the MCF outlet, after reaching the steady-state condition (i.e., five times the reactor volume processed) and analyzed. Experiments were carried out isothermally at room temperature $\left(\sim 25^{\circ} \mathrm{C}\right)$ and the fluid temperature flowing through the reactor remained unchanged. The $\mathrm{pH}$ of the feed solution during the each experimental run was constant. In addition, BE removal was insensitive to $\mathrm{pH}$ in the range 4.0-8.0 [22].

The lamp irradiance and thus the incident flux in the capillaries was varied by changing the electrical power supplied to the lamp from $4.5 \mathrm{~W}$ to $8.0 \mathrm{~W}$ using a variable power supply unit. The photon fluxes per unit volume emitted by the UV lamp $\left(\mathrm{I}_{0 / \mathrm{MCF}} / \mathrm{V}_{\mathrm{MCF}}\right)$ for each power setting were estimated with an indirect approach by $\mathrm{H}_{2} \mathrm{O}_{2}$ actinometry [41,42] and the calculated values were 
$1.26 \cdot 10^{-2}$ ein $\cdot \mathrm{s}^{-1} \cdot \mathrm{L}^{-1}$ and $1.92 \cdot 10^{-2} \mathrm{ein} \cdot \mathrm{s}^{-1} \cdot \mathrm{L}^{-1}$, respectively. The MCF average optical path length $\left(l_{\mathrm{MCF}}\right)$ was $152 \mu \mathrm{m}$ (Figure 1a).

\subsubsection{Cylindrical batch photoreactor}

In the cylindrical batch photoreactor $\left(\mathrm{V}_{\text {batch }}=0.480 \mathrm{l}\right)$ the $\mathrm{BE} / \mathrm{H}_{2} \mathrm{O}_{2}$ aqueous solution was irradiated with a low-pressure mercury monochromatic lamp (Helios Italquartz, HGL10T5L, 17W nominal power emitting at $253.7 \mathrm{~nm})$ immersed in the center axis. The photon path length $\left(\mathrm{l}_{\text {batch }}\right)$ was 2.20 $\mathrm{cm}$ (Figure 1b). The reactor was thermostated at $25^{\circ} \mathrm{C}$ and wrapped with aluminum foil. At the top, the reactor had two inlets for feeding reactants and for collecting samples. The photon flux emitted by the UV lamp at $253.7 \mathrm{~nm}$ by $\mathrm{H}_{2} \mathrm{O}_{2}$ actinometry was $\mathrm{I}_{0 / \text { batch }}=2.86 \cdot 10^{-6}$ ein $\cdot \mathrm{s}^{-1}$. The primary use of the cylindrical batch photoreactor was to provide sufficient liquid volumes to carry out the toxicity tests on samples collected at different reaction times.

\subsubsection{Optimization and validation procedures}

The unknown kinetic parameters were estimated from the results obtained from the MCF photoreactor. $\mathrm{k}_{\mathrm{OH} / \mathrm{BE}}$ was evaluated trough the competition kinetics method in the presence of benzoic acid $[33,34]$. Subsequently, the reaction rate constants for the radical scavengers $\left(\mathrm{k}_{\mathrm{sca}}^{\prime}\right)$ and by-products $\left(\mathrm{k}_{\mathrm{OH} / \mathrm{BE}}\right)$ were estimated by numerical modelling.

After the determination of the reaction rate constants of the elementary reactions in the proposed reaction mechanism, additional experimental runs were executed, in both MCF and cylindrical batch photoreactors, to validate the proposed kinetic model, without further adjustment of the model parameters. Figure 2 summarizes graphically the optimization and validation procedures used.

\subsubsection{Ecotoxicity assessment apparatus and procedures}

Ecotoxicity assessments of untreated and treated water samples were carried out with four different organisms including two primary producers, the freshwater alga $R$. subcapitata and the plant $V$. 
faba and two primary consumers, the cladoceran D. magna and the nematode C. elegans. These

essential components of the food chain are highly sensitive analytical tools to screen the toxicity of environmental chemicals [43-48].

$80 \mu \mathrm{L} \cdot \mathrm{L}^{-1}$ of catalase (used to destroy the residual hydrogen peroxide) were diluted into the fresh samples collected from the batch reactor at the three different reaction times with the aim of neglecting the toxic effect of $\mathrm{H}_{2} \mathrm{O}_{2}$ present into the solutions at the concentration of 6.3 mM. Negative tests were carried out on aqueous solutions containing $6.3 \mathrm{mM}$ of hydrogen peroxide and $80 \mu \mathrm{L} \cdot \mathrm{L}-1$ of catalase (used to destroy the residual hydrogen peroxide), to verify that the mixture did not exert negative effects on the four target organisms.

An ISO protocol [49] was used to measure the algal growth inhibition with $R$. subcapitata. For each sample, six replicates were inoculated with $10^{7}$ algal cells $\cdot \mathrm{L}^{-1}$ in well plates and incubated for $72 \mathrm{~h}$ test at $23 \pm 2{ }^{\circ} \mathrm{C}$ under continuous illumination (in the irradiance range of $120-60 \mu$ ein $\cdot \mathrm{m}^{-2} \mathrm{~s}^{-1}$ ).

The specific growth rate $(\mu)$ of $R$. subcapitata in each replicate was calculated from the logarithmic increase in cell density in the interval 0 to $72 \mathrm{~h}$ as follows:

$\mu=\frac{\ln N_{i}-\ln N_{0}}{t_{i}-t_{0}}$

where $\mathrm{N}_{\mathrm{i}}$ represents the cell concentration at time $t_{\mathrm{i}}$. Results were expressed as the mean $( \pm \operatorname{standard}$ deviation) of the percentage inhibition of cell growth $v s$. negative controls.

The toxicity of the samples on Daphnia magna was assessed by viability, morphological alterations, heartbeat frequency, and immobilization endpoints. ISO 6341 protocol [50] was followed to evaluate the acute bioassay at 24 and 48 hours. Test daphnids were generated from a laboratory breeding facility operating according to OECD 202 [51]. For each sample, four replicates with 20 daphnids $(<24 \mathrm{~h}$ old $)$ in each well were tested in static tests. The immobilization frequencies were recorded at 24 and 48 hours. The tests were considered valid if the immobilization in the control did not exceed $10 \%$. The daphnids heart rate was counted with the stereomicroscope after an 
acclimation period (120 s). The heart rate readings were taken per daphnids, at regular intervals (30

s) for total time of $60 \mathrm{~min}$.

Toxicity tests in C. elegans, wild-type strain N2 variant Bristol, were performed using an agesynchronous L4-larval nematodes method [52]. Ten worms at a time were placed into 24-well tissue culture plates containing $0.5 \mathrm{~mL}$ of water sample and $0.5 \mathrm{~mL}$ of $\mathrm{K}$-medium as negative control. All treatments were done in triplicate and without feeding the worms. The worms were exposed for 24 $\mathrm{hr}$ at $20^{\circ} \mathrm{C}$. The number of dead worms was determined by absence of movement monitored by the stereomicroscope.

The samples genotoxicity potential was performed on Vicia faba root tips [53]. Bioassays used 90 mm Petri dishes with one Whatman No. 1 filter paper as support. After adding 5 seeds and $6 \mathrm{~mL}$ of the sample (previously equilibrated for $24 \mathrm{~h}$ in the dark), the Petri dishes were incubated in the dark at $22{ }^{\circ} \mathrm{C}$ for $96 \mathrm{~h}$. After exposure, the $V$. faba root tips were immersed for $24 \mathrm{~h}$ in $1: 3$ acetic acid:ethanol solutions, then were cut, stained in Schiff's Reagent using Feulgens method [54] and squashed on microscope slides. The micronucleus frequency $(\mathrm{MN})$ was evaluated in $1 \cdot 10^{3}$ cells of $V$. faba seeds. Positive tests on $V$. faba ecotoxicity were perfomed with an aqueous solution of maleic hydrazide $(5 \mathrm{ppm})$. Whenever possible, ecotoxicity data were expressed as the EC50 values and its $95 \%$ confidence intervals calculated by non-linear regression.

The significance of the differences between the mean values of different tests and controls was assessed by Student's test and analysis of variance (ANOVA) with a 0.05 significance level. Moreover, post-hoc analysis were carried on with Dunnett's method and Tukey's test [55-56].

\section{Results and discussions}

\subsection{Competition kinetic method for $\mathrm{k}_{\mathrm{HO} / \mathrm{BE}}$ value evaluation}

Competition kinetics was used to evaluate the second-order rate constant $\mathrm{k}_{\mathrm{OH} / \mathrm{BE}}$ between ${ }^{\circ} \mathrm{OH}$ radicals and $\mathrm{BE}$ which compares the substrate concentration decay to that of the reference compound, benzoic acid (BA) [33,34]. With this procedure, the estimation of $\mathrm{k}_{\mathrm{OH} / \mathrm{BE}}$ was not 
influenced by the reactor geometry and by the presence of scavengers such as water impurities since

both $\mathrm{BE}$ and $\mathrm{BA}$ were exposed to the same ${ }^{\circ} \mathrm{OH}$ radical concentration. The $\mathrm{BE}$ and $\mathrm{BA}$ mass balances in the MCF are:

$$
\begin{aligned}
& \frac{\mathrm{d}[\mathrm{BE}]}{\mathrm{d} \tau}=-\mathrm{k}_{\mathrm{OH} / \mathrm{BE}} \cdot[\mathrm{BE}] \cdot\left[{ }^{\circ} \mathrm{OH}\right] \\
& \frac{\mathrm{d}[\mathrm{BA}]}{\mathrm{d} \tau}=-\mathrm{k}_{\mathrm{OH} / \mathrm{BA}} \cdot[\mathrm{BA}] \cdot\left[{ }^{\circ} \mathrm{OH}\right]
\end{aligned}
$$

where $\tau$ is the space-time and $\mathrm{k}_{\mathrm{OH} / \mathrm{BA}}=5.9 \cdot 10^{9} \mathrm{M}^{-1} \cdot \mathrm{s}^{-1}$ the kinetic rate constant of the reaction between the ${ }^{\circ} \mathrm{OH}$ radicals and $\mathrm{BA}[33,34]$.

Integrating Eqs. (4) and (5) yields the linear relation between the logarithms of the normalized BE and BA concentrations:

$$
\ln \left(\frac{[\mathrm{BE}]}{[\mathrm{BE}]_{0}}\right)=\frac{\mathrm{k}_{\mathrm{OH} / \mathrm{BE}}}{\mathrm{k}_{\mathrm{OH} / \mathrm{BA}}} \cdot \ln \left(\frac{[\mathrm{BA}]}{[\mathrm{BA}]_{0}}\right)
$$

Three experimental runs varying the $\mathrm{H}_{2} \mathrm{O}_{2}$ concentration were performed to evaluate $\mathrm{k}_{\mathrm{OH} / \mathrm{BE}}$ (Table 1). On the basis of the results reported in Table 1 , an average value of $\mathrm{k}_{\mathrm{OH} / \mathrm{BE}}=5.13 \cdot 10^{9} \pm 2.6 \cdot 10^{8}$ $\mathrm{M}^{-1} \cdot \mathrm{s}^{-1}$ was calculated.

\subsection{Evaluation of by-products and scavenging effect}

3.2.1 Reaction kinetics model development and validation in the MCF photoreactor and evaluation of the reaction by-products effect

A simplified reaction kinetics mechanism was developed to describe the removal of BE by $\mathrm{UV}_{254} / \mathrm{H}_{2} \mathrm{O}_{2}$ process in water in the absence of scavengers (milli-Q water) (Table 2). It takes into account both, direct BE photolysis ( $\left.\mathrm{r}_{1}\right)$ with the consequent production of by-products (BPs) and hydrogen peroxide photolysis $\left(\mathrm{r}_{2}\right)$ with the generation of ${ }^{\circ} \mathrm{OH}$ radicals, which further attack $\mathrm{H}_{2} \mathrm{O}_{2}$ $\left(\mathrm{r}_{3}\right)$, BE $\left(\mathrm{r}_{4}\right)$, and all the generated by-products, considered as a pseudo-component (BPs) ( $\left.\mathrm{r}_{5}\right)$. Finally, the peroxyl radicals $\left(\mathrm{HO}_{2}^{*}\right)$ produced through the reaction $\mathrm{r}_{4}$ undergo radical termination reaction to generate hydrogen peroxide $\left(\mathrm{r}_{6}\right)$. 
The mole balances on hydroxyl and peroxyl radicals in the MCF are:

where $\mathrm{F}_{\mathrm{H}_{2} \mathrm{O}_{2}}$ is the rate of photolysis of $\mathrm{H}_{2} \mathrm{O}_{2}$ expressed as:

$\mathrm{F}_{\mathrm{H}_{2} \mathrm{O}_{2}}=\frac{\Phi_{254}^{\mathrm{H}_{2} \mathrm{O}_{2} \cdot \mathrm{I}_{0} / \mathrm{MCF}}}{\mathrm{V}_{\mathrm{MCF}}} \cdot\left(1-\exp \left(-2.3 \cdot \mathrm{l}_{\mathrm{MCF}} \cdot\left(\varepsilon_{254}^{\mathrm{BE}} \cdot[\mathrm{BE}]+\varepsilon_{254}^{\mathrm{H}_{2} \mathrm{O}_{2}} \cdot\left[\mathrm{H}_{2} \mathrm{O}_{2}\right]\right)\right)\right) \cdot \mathrm{f}_{\mathrm{H}_{2} \mathrm{O}_{2}}$

where $\mathrm{f}_{\mathrm{H}_{2} \mathrm{O}_{2}}$ is the $\mathrm{UV}_{254}$ radiation fraction absorbed by $\mathrm{H}_{2} \mathrm{O}_{2}$.

Assuming steady-state of all radical species [58], the concentrations of $\mathrm{HO}^{\circ}$ and $\mathrm{HO}_{2}^{\circ}$ are:

$$
\begin{aligned}
& {\left[{ }^{\cdot} \mathrm{OH}\right]_{\mathrm{Ss}}=\frac{2 \cdot \mathrm{F}_{\mathrm{H}_{2} \mathrm{O}_{2}}}{\mathrm{k}_{\mathrm{h}} \cdot\left[\mathrm{H}_{2} \mathrm{O}_{2}\right]+\mathrm{k}_{\mathrm{OH} / \mathrm{BE}} \cdot[\mathrm{BE}]+\mathrm{k}_{\mathrm{OH} / \mathrm{BP}} \cdot[\mathrm{BPs}]}} \\
& {\left[\mathrm{HO}_{2}^{*}\right]_{\mathrm{SS}}^{2}=\frac{\mathrm{k}_{\mathrm{h}}}{\mathrm{k}_{\mathrm{t}}} \cdot \frac{2 \cdot \mathrm{F}_{\mathrm{H}_{2} \mathrm{O}_{2}}}{\mathrm{k}_{\mathrm{h}} \cdot\left[\mathrm{H}_{2} \mathrm{O}_{2}\right]+\mathrm{k}_{\mathrm{OH} / \mathrm{BE}} \cdot[\mathrm{BE}]+\mathrm{k}_{\mathrm{OH} / \mathrm{BP}} \cdot[\mathrm{BPs}]}}
\end{aligned}
$$

On the other hand, the mole balances on $\mathrm{BE}$ and $\mathrm{H}_{2} \mathrm{O}_{2}$ are:

$$
\begin{aligned}
& \frac{\mathrm{d}[\mathrm{BE}]}{\mathrm{d} \tau}=-\mathrm{F}_{\mathrm{BE}}-\mathrm{k}_{\mathrm{OH} / \mathrm{BE}} \cdot[\mathrm{BE}] \cdot\left[\cdot{ }^{\circ} \mathrm{OH}\right] \\
& \frac{\mathrm{d}\left[\mathrm{H}_{2} \mathrm{O}_{2}\right]}{\mathrm{d} \tau}=-\mathrm{F}_{\mathrm{H}_{2} \mathrm{O}_{2}}-\mathrm{k}_{\mathrm{h}} \cdot\left[\cdot{ }^{\circ} \mathrm{OH}\right] \cdot\left[\mathrm{H}_{2} \mathrm{O}_{2}\right]+\mathrm{k}_{\mathrm{t}} \cdot\left[\mathrm{HO}_{2}^{\cdot}\right]^{2}
\end{aligned}
$$

The term $\mathrm{F}_{\mathrm{BE}}$ in Eq. (12), is the rate of $\mathrm{BE}$ direct photolysis expressed as:

$$
\mathrm{F}_{B E}=\frac{\Phi_{254}^{B E} \cdot \mathrm{I}_{0 / \mathrm{MCF}}}{\mathrm{V}_{\mathrm{MCF}}} \cdot\left(1-\exp \left(-2.3 \cdot \mathrm{l}_{\mathrm{MCF}} \cdot\left(\varepsilon_{254}^{\mathrm{BE}} \cdot[\mathrm{BE}]+\varepsilon_{254}^{\mathrm{H}_{2} \mathrm{O}_{2}} \cdot\left[\mathrm{H}_{2} \mathrm{O}_{2}\right]\right)\right)\right) \cdot \mathrm{f}_{\mathrm{BE}}
$$

where $\mathrm{f}_{\mathrm{BE}}$ is the fraction of $\mathrm{UV}_{254}$ radiation absorbed by $\mathrm{BE}$.

Replacing Eqs. (10-11) into (12-13) yields:

$$
\begin{aligned}
& \frac{\mathrm{d}[\mathrm{BE}]}{\mathrm{d} \tau}=-\mathrm{F}_{\mathrm{BE}}-\frac{2 \cdot \mathrm{k}_{\mathrm{OH} / \mathrm{BE}} \cdot \mathrm{F}_{\mathrm{H}_{2} \mathrm{O}_{2} \cdot[\mathrm{BE}]}}{\mathrm{k}_{\mathrm{h}} \cdot\left[\mathrm{H}_{2} \mathrm{O}_{2}\right]+\mathrm{k}_{\mathrm{OH} / \mathrm{BE}} \cdot[\mathrm{BE}]+\mathrm{k}_{\mathrm{OH} / \mathrm{BP}} \cdot\left([\mathrm{BE}]_{0}-[\mathrm{BE}]\right)} \\
& \frac{\mathrm{d}\left[\mathrm{H}_{2} \mathrm{O}_{2}\right]}{\mathrm{d} \tau}=-\mathrm{F}_{\mathrm{H}_{2} \mathrm{O}_{2}}-\frac{\mathrm{k}_{\mathrm{h}} \cdot \mathrm{F}_{\mathrm{H}_{2} \mathrm{O}_{2}} \cdot\left[\mathrm{H}_{2} \mathrm{O}_{2}\right]}{\mathrm{k}_{\mathrm{h}} \cdot\left[\mathrm{H}_{2} \mathrm{O}_{2}\right]+\mathrm{k}_{\mathrm{OH} / \mathrm{BE}} \cdot[\mathrm{BE}]+\mathrm{k}_{\mathrm{OH} / \mathrm{BP}} \cdot\left([\mathrm{BE}]_{0}-[\mathrm{BE}]\right)}
\end{aligned}
$$

where the by-product concentration equals the amount of BE reacted. 
The integration of two ODEs (Eqs. 15-16) results in the $\mathrm{BE}$ and $\mathrm{H}_{2} \mathrm{O}_{2}$ concentration profiles vs space time in the MCF. The unknown rate constant $\mathrm{k}_{\mathrm{HO} / \mathrm{BP}}$ was estimated by an iterative optimization procedure that minimized the square of the differences between the calculated $(y)$ and experimental (c) concentrations of each species (optimization mode) [59]. Specifically, the objective function $(\Phi)$ was expressed as:

$\Phi=\sum_{\mathrm{g}=1}^{\mathrm{h}} \sum_{\mathrm{i}=1}^{\mathrm{l}} \sum_{\mathrm{m}=1}^{\mathrm{n}}\left(\mathrm{y}_{\mathrm{g}, \mathrm{i}, \mathrm{m}}-\mathrm{c}_{\mathrm{g}, \mathrm{i}, \mathrm{m}}\right)^{2}$

where $h, l$ and $n$ respectively represent the number of experimental data recorded in each experiment, the number of the reacting species, and the number of experiment used in the optimization procedure. The percentage standard deviation on the $\mathrm{i}^{\text {th }}$ species was calculated as follows:

$\sigma_{i}(\%)=100 \cdot \frac{1}{\bar{c}_{i}} \sqrt{\sum_{g=1}^{h} \frac{\left(y_{i, g}-c_{i, g}\right)^{2}}{h-p}}$

where $\bar{c}_{\mathrm{i}}$ represents the average measured concentration of the $i^{\text {th }}$ species and $p$ the number of the unknown parameters to be estimated. In this case, $p=1$, since $\mathrm{k}_{\mathrm{HO} / \mathrm{BP}}$ was the only unknown parameter.

Table 3 (runs 1-6) show the experimental conditions of the runs used in the optimization procedure and the corresponding standard deviation $\left(\sigma_{\dot{\mathrm{i}}}\right)$ on $\mathrm{BE}$ and $\mathrm{H}_{2} \mathrm{O}_{2}$ from the model. The unknown rate constant was therefore estimated as $\mathrm{k}_{\mathrm{OH} / \mathrm{BP}}=8.93 \cdot 10^{9} \pm 1.0 \cdot 10^{9} \mathrm{M}^{-1} \mathrm{~s}^{-1}(95 \%$ confidence interval).

The $\mathrm{UV}_{254} / \mathrm{H}_{2} \mathrm{O}_{2} / \mathrm{BE}$ reaction kinetics model was validated by predicting the results of four additional runs carried out at a different photon flux (Table 3, runs 1s-4s) without further adjustment of the reaction rate constant estimated (simulation mode). Figure 3 show excellent prediction of the concentrations of $\mathrm{BE}$ and $\mathrm{H}_{2} \mathrm{O}_{2}$ at different space time. The standard deviations calculated for both $\mathrm{BE}$ and $\mathrm{H}_{2} \mathrm{O}_{2}$ (Table 3) were found to be below $1.41 \%$ which demonstrated a very close agreement between the kinetic model and the experimental results. 


\subsubsection{Model validation on a batch photoreactor}

The cylindrical batch reactor, reported in Figure $1 \mathrm{~b}$, is characterized by a drastically different geometry compared to the MCF, but Eqs. (15-16) of the reaction kinetics model are still valid once the parameters related to the reactor geometry $\mathrm{F}_{\mathrm{BE}}$ and $\mathrm{F}_{\mathrm{H} 2 \mathrm{O} 2}$ were changed (Eqs. 19-20) and spacetime $\tau$ replaced by reaction time $t:$

$$
\begin{aligned}
& \mathrm{F}_{\mathrm{BE}}=\frac{\Phi_{254}^{B E} \cdot \mathrm{I}_{0} / \text { batch }}{\mathrm{V}_{\text {batch }}} \cdot\left(1-\exp \left(2.3 \cdot \mathrm{l}_{\text {batch }} \cdot\left(\varepsilon_{254}^{\mathrm{BE}} \cdot[\mathrm{BE}]+\varepsilon_{254}^{\mathrm{H}_{2} \mathrm{O}_{2}} \cdot\left[\mathrm{H}_{2} \mathrm{O}_{2}\right]\right)\right)\right) \cdot \mathrm{f}_{\mathrm{BE}} \\
& \mathrm{F}_{\mathrm{H}_{2} \mathrm{O}_{2}}=\frac{\Phi_{254}^{\mathrm{H}_{2} \mathrm{O}_{2} \cdot \mathrm{I}_{0} / \text { batch }}}{\mathrm{V}_{\text {batch }}} \cdot\left(1-\exp \left(2.3 \cdot \mathrm{l}_{\text {batch }} \cdot\left(\varepsilon_{254}^{\mathrm{BE}} \cdot[\mathrm{BE}]+\varepsilon_{254}^{\mathrm{H}_{2} \mathrm{O}_{2}} \cdot\left[\mathrm{H}_{2} \mathrm{O}_{2}\right]\right)\right)\right) \cdot \mathrm{f}_{\mathrm{H}_{2} \mathrm{O}_{2}}
\end{aligned}
$$

An experimental $\mathrm{UV}_{254} / \mathrm{H}_{2} \mathrm{O}_{2} / \mathrm{BE}$ run was carried out in the cylindrical batch photoreactor to further validate the reaction kinetics model of $\mathrm{BE}$ oxidation by the $\mathrm{UV}_{254} / \mathrm{H}_{2} \mathrm{O}_{2}$ process. The profiles of $\mathrm{BE}$ and $\mathrm{H}_{2} \mathrm{O}_{2}$ concentrations against reaction time were compared with those obtained by the proposed reaction kinetic model, without further adjustment of the previously estimated parameters (validation mode). The results in Figure 4 show a robust prediction capability by the model of the experimental results even though the reactor geometry radically changed in comparison to the MCF. $\sigma_{\mathrm{i}}(\%)$ of $\mathrm{BE}$ and $\mathrm{H}_{2} \mathrm{O}_{2}$ were $0.56 \%$ and $0.28 \%$, respectively.

\subsubsection{Evaluation of scavenging effect}

The role of radical scavenging species [60] was evaluated in three further water matrices including synthetic (SWW) and real (RWW) wastewater, and surface water (SurW) to provide a realistic analysis of the effectiveness of the $\mathrm{UV}_{254} / \mathrm{H}_{2} \mathrm{O}_{2}$ process on the removal of BE. For this purpose the reaction kinetics model of $\mathrm{BE}$ oxidation was modified (Eqs. 21-22) to include the effect of scavengers:

$$
\frac{\mathrm{d}[\mathrm{BE}]}{\mathrm{d} \tau}=-\mathrm{F}_{\mathrm{BE}}-\frac{2 \cdot \mathrm{k}_{\mathrm{HO} / \mathrm{BE}} \cdot \mathrm{F}_{\mathrm{H}_{2} \mathrm{O}_{2}} \cdot[\mathrm{BE}]}{\mathrm{k}_{\mathrm{h}} \cdot\left[\mathrm{H}_{2} \mathrm{O}_{2}\right]+\mathrm{k}_{\mathrm{OH} / \mathrm{BE}} \cdot[\mathrm{BE}]+\mathrm{k}_{\mathrm{OH} / \mathrm{BP}} \cdot\left([\mathrm{BE}]_{0}-[\mathrm{BE}]\right)+\mathrm{k}_{\mathrm{sca}}^{\prime}}
$$




$$
\frac{\mathrm{d}\left[\mathrm{H}_{2} \mathrm{O}_{2}\right]}{\mathrm{d} \tau}=-\mathrm{F}_{\mathrm{H}_{2} \mathrm{O}_{2}}-\frac{\mathrm{k}_{\mathrm{h}} \cdot \mathrm{F}_{\mathrm{H}_{2} \mathrm{O}_{2}} \cdot\left[\mathrm{H}_{2} \mathrm{O}_{2}\right]}{\mathrm{k}_{\mathrm{h}} \cdot\left[\mathrm{H}_{2} \mathrm{O}_{2}\right]+\mathrm{k}_{\mathrm{OH} / \mathrm{BE}} \cdot[\mathrm{BE}]+\mathrm{k}_{\mathrm{OH} / \mathrm{BP}} \cdot\left([\mathrm{BE}]_{0}-[\mathrm{BE}]\right)+\mathrm{k}_{\mathrm{sca}}^{\prime}}
$$

where $\mathrm{k}_{\mathrm{sca}}^{\prime}=\mathrm{k}_{\mathrm{sca}} \cdot[\mathrm{SCA}]$ is the pseudo-first order rate constant of the reaction between the ${ }^{\circ} \mathrm{OH}$ radicals and the scavenger species. Since similar removal rates of BE in SWW and RWW in the MCF has been observed [22] and following the same optimization methodology reported earlier, $\mathrm{k}_{\mathrm{sca} / \mathrm{SwW}}^{\prime}=\mathrm{k}_{\mathrm{sca} / \mathrm{RWw}}^{\prime}=4.01 \cdot 10^{5} \pm 1.8 \cdot 10^{4} \mathrm{~s}^{-1}$ was estimated from three experimental runs in the MCF (run 1-3, Table 4) with a 97.5\% confidence interval.

The model was validated by predicting the results of four additional runs carried out with both SWW and RWW (Table 4, runs 1s-4s) without further adjustment of the reaction rate constant estimated (validation mode). Although a small systematic error appeared on BE trends of run $2 \mathrm{~s}$ and run $3 \mathrm{~s}$, the comparison between experimental and theoretical results (Figure 5) and the percentage standard deviations on the measured species (Table 4) highlights a good capability of the model of predicting the $\mathrm{BE}$ and $\mathrm{H}_{2} \mathrm{O}_{2}$ consumption in both SWW and RWW.

The procedure was repeated for two further runs executed with SurW in the MCF (Table 4, runs 45 , optimization mode) yielding of $\mathrm{k}_{\mathrm{sca} / \mathrm{SurW}}^{\prime}=6.82 \cdot 10^{5} \pm 3.8 \cdot 10^{4} \mathrm{~s}^{-1}$, which were validated with two further experiments (Table 4, runs 4s-6s, and Figure 6, validation mode) showing a good model prediction capability of the experimental results.

\subsection{Ecotoxicity and genotoxicity of treated water}

Ecotoxicological tests were performed on samples collected from $\mathrm{UV}_{254} / \mathrm{H}_{2} \mathrm{O}_{2} / \mathrm{BE}$ experiments performed in the cylindrical batch reactor with an aqueous solution containing $\mathrm{BE}$ and $\mathrm{H}_{2} \mathrm{O}_{2}$ at initial concentrations of $3.5 \cdot 10^{-3} \mathrm{M}(10 \mathrm{ppm})$ and $6.3 \cdot 10^{-3} \mathrm{M}(214 \mathrm{ppm})$ respectively. In addition to the sample $\left(\mathrm{t}_{0}\right)$ collected at time zero, two further samples were collected at reaction time of $1.5 \mathrm{~min}$ $\left(\mathrm{t}_{\mathrm{f}}\right)$ corresponding to almost complete BE conversion (Figure 4) and at 3.0 min $\left(2 \mathrm{t}_{\mathrm{f}}\right.$ ) reasonably representative of a solution containing secondary oxidation by-products. Within the reaction range chosen (0 - $3.0 \mathrm{~min})$, TOC analysis did not evidenced any noticeable mineralization phenomena. 
The exposure to D. magna for $24 \mathrm{~h}$ and $48 \mathrm{~h}$ of contact time to untreated and treated solutions were not showed since no significant immobilization was induced compared to negative controls. A detailed inspection of daphnids at $48 \mathrm{~h}$ under static conditions confirmed the absence of clear morphological changes, as well as, a comparable growth in all groups of exposure (t-test). Microscopically observations showed an increase, compared to the control groups, in the size of lipid droplets in juveniles of $D$. magna after the exposure to $t_{0}$ and $t_{f}$ samples (Figure 7 ). These droplets were already observed when daphnids were exposed to various toxic substances such as insecticide or nanoparticles [61-63]. Generally, the accumulated lipid droplets indicate abnormal synthesis or metabolism of lipids and it is plausible that samples corresponding to $t_{0}$ and $t_{f}$ reaction times could alter lipid homeostasis in D. magna. When exposed to samples treated for $2 \mathrm{t}_{\mathrm{f}}$, daphnids showed a yellow pigmentation of the body (Figure 7) which indicates BE toxicity [64]. The heartbeat rate of daphnids exposed to samples collected at different treatment times was similar to that observed for the control group (t-test). A previous study, carried out on the exposure of zebrafish (Danio rerio) embryo to BE contaminated solutions, confirms this findings since any appreciable change of the cardiac rate of the tested specie was observed [17].

Growth inhibition data for algae $R$. subcapitata exposed to BE contaminated solution at different reaction times are shown in Figure 8. The maximum effect $(12.01 \%)$ was observed when algal suspensions were exposed to the sample collected at $t_{f}$, but even lower inhibitory effects were detected in $\mathrm{t}_{0}$ and $2 \mathrm{t}_{\mathrm{f}}$ (10.9 and $8.3 \%$ of inhibition respectively), with significant differences of the treated samples to the control. A similar effect was reported on green algae exposure to anatoxin [65], a neurotoxin structurally similar to benzoylecgonine [66].

When $C$. elegans was exposed for $24 \mathrm{~h}$ at $20{ }^{\circ} \mathrm{C}$ to undiluted samples, the archived percentage mortality of worms ranged from 90 and $100 \%$ for all tested samples (Figure 9). The viability of $C$. elegans increased after exposure of $2 \mathrm{t}_{\mathrm{f}}$ undiluted solution, however this effect was not statistically different than $t_{0}$ and $t_{\mathrm{f}}$ samples. In contrast, the exposure of $C$. elegans to diluted samples showed that $50 \%$ survival of nematodes occurred at $6 \%, 8 \%$ and $22 \%$ dilution for the $\mathrm{t}_{0}, \mathrm{t}_{\mathrm{f}}$ and $2 \mathrm{t}_{\mathrm{f}}$ samples 
respectively. On the basis of these results the $\mathrm{EC}_{50}$ was estimated as $0.6 \pm 0.1 \mathrm{ppm}$. The nematodes offered higher sensitivity to BE and its reaction by-products, recognizing the role of $C$. elegans for drug discovery and neurobehavioral toxicity [67-69].

$V$. faba was exposed to the $\mathrm{t}_{0}, \mathrm{t}_{\mathrm{f}}$ and $2 \mathrm{t}_{\mathrm{f}}$ samples though liquid phase exposure routes. All samples showed similar responses, but significantly different in relation to the negative control. A remarkable increase of $\mathrm{MN}$ was found for exposures to $\mathrm{t}_{\mathrm{f}}$ sample that was comparable to $\mathrm{MN}$ in the positive control ( $\mathrm{Ctr}+)$ (Figure 10) suggesting that the first generation of BE by-products induce a higher MN generation into $V$. faba root tips. Additional tests with diluted samples at a ratio of 1:2 showed a MN frequency not significantly different compared to the negative control.

In a previous paper [70], 125 acute chronic ratio (ACR) values for 84 chemicals and 11 species of aquatic organisms were summarized. The ACR, expressed by the ratio of the acute EC50 and the chronic toxicity (maximum acceptable toxicant concentration, MATC), was found to be in the range 1.0-1.8 $10^{4}$. Considering an ACR equal to $10^{3}$ and the EC50 of BE on $C$. elegans evaluated in this work $(0.6 \mathrm{ppm})$, a chronic toxic effect could be observed on nematodes at the BE concentration equal to $0.6 \mathrm{ppb}$. In particular, the predicted MATC value is in agreement with the results previously reported [13-15] regarding the negative effect of BE contaminated water solutions $(0.5$ and $1.0 \mathrm{ppb})$ on Dreissena polymorpha. Moreover, the ecotoxicity and genotoxicity tests carried out with the sample withdrawn at $t_{f}$ suggest, considering the same ACR value, that it is possible that the by-products, deriving by the $\mathrm{UV}_{254} / \mathrm{H}_{2} \mathrm{O}_{2}$, treatment of a solution containing $\mathrm{BE}$ at the concentration of $1 \mathrm{ppb}$, could exert a negative chronic effect on living organisms.

All these considerations could be certainly validated through dedicated chronic tests, but the results regarding the acute toxicity of $\mathrm{BE}$ and its by-products on $C$. elegans and $V \cdot f a b a$, suggest that chronic negative effects could also be observed on living organisms subjected to the BE concentrations founded in STP effluents and surface waters. 


\section{Conclusions}

Benzoylecgonine removal by the $\mathrm{UV}_{254} / \mathrm{H}_{2} \mathrm{O}_{2}$ treatment was modeled using the results collected in ultrarapid experiments performed in the MCF reactor and using very small water volumes. The reaction kinetics model was successfully validated on an experimental run carried out on a radically different and much bigger cylindrical batch reactor, thus demonstrating the possibility of using a MCF reactor for ultrarapid photochemistry investigations. By competition kinetics the rate constant of the reaction between $\mathrm{BE}$ and the photogenerated $\mathrm{HO}$ radicals in milli-Q water was estimated as $\mathrm{k}_{\mathrm{OH} / \mathrm{BE}}=5.13 \cdot 10^{9} \mathrm{M}^{-1} \mathrm{~s}^{-1}$. The reaction kinetic constant of the reaction between the HO radicals and $\mathrm{BE}$ transformation by-products resulted be equal to $8.93 \cdot 10^{9} \mathrm{M}^{-1} \mathrm{~s}^{-1}$ while the ones between the $\mathrm{HO}$ radicals and the scavengers present into RWW and SurW were estimated as $4.01 \cdot 10^{5} \mathrm{~s}^{-1}$, and $6.82 \cdot 10^{5} \mathrm{~s}^{-1}$ respectively.

The growth of $R$. subcapitata and the immobility of $D$. magna were not significantly influenced during the exposure to all the samples. However, an increase in lipid droplets was observed in $D$. magna, probably related to the presence of $\mathrm{BE}$ and its photodegradation by-products, but the significance of the response needs further investigations.

The survival of $C$. elegans dramatically decreased in presence of the untreated and treated $\mathrm{BE}$ solutions. Marked DNA damages on $V$. faba were found in samples collected at the reaction time corresponding to the complete conversion of $\mathrm{BE}$, thus indicating a toxic effect ascribed to the presence of primary by-products. Our results herein demonstrate that this photocatalytic process is very effective, with the prospect development of technologies for BE detoxification by second generation of BE by-products that reduce the acute eco-toxicity of treated solutions.

Even though the concentrations of $\mathrm{BE}$ were higher than those found into the environment, the results on acute toxicity suggest further investigations on the long-term effects of $\mathrm{BE}$ and its $\mathrm{UV}_{254} / \mathrm{H}_{2} \mathrm{O}_{2}$ transformation by-products on environmental health. 


\section{Acknowledgment}

The Authors are grateful to ERASMUS-Mobility Student Program, to Patrick Hester (Lamina Dielectrics Ltd) for donating the MCF material, to Ian Belk for allowing access to the STP of Loughborough and COST Action ES1403 for supporting this scientific cooperation.

\section{References}

[1] World Drug Report, United Nations Office on Drugs and Crime, Vienna 1-112, 2012.

[2] S. Castiglioni, E. Zuccato, C. Chiarabrando, R. Fanelli, R. Bagnati, Mass spectrometric analysis of illicit drugs in wastewater and surface water, Mass Spectrom. Rev. 27 (2008) 378-394.

[3] R.J. Irvine, C. Kostakis, P.D. Felgate, E.J. Jaehne, C. Chen, J.M. White, Population drug use in Australia: a wastewater analysis, Forensic Sci. Int. 210 (2011) 69-73.

[4] F. Yin-Lai, R. Bruno, H.W. Leung, P.K. Thai, C. Ort, S. Carter, K. Thompson, P.K.S. Lam, J.F. Mueller, Estimating daily and diurnal variations of illicit drug use in Hong Kong: a pilot study of using wastewater analysis in an Asian metropolitan city, Forensic Sci. Int. 233 (2013) 126-132.

[5] B. Du, A.E. Price, W.C. Scott, L.A. Kristofco, A.J. Ramirez, C.K. Chambliss, J.C. Yelderman, B.W. Brooks, Comparison of contaminants of emerging concern removal, discharge, and water quality hazards among centralized and on-site wastewater treatment system effluents receiving common wastewater influent, Sci. Total Environ. 466-467 (2014) 976-984.

[6] C. Repice, M. Dal Grande, R. Maggi, R. Pedrazzani, Licit and illicit drugs in a wastewater treatment plant in Verona, Italy, Sci. Total Environ. 463-464 (2013) 27-34.

[7] M. Huerta-Fontela, M.T. Galceran, J. Martin, F. Ventura, Occurrence of psychoactive stimulatory drugs in wastewaters in north-eastern Spain, Sci. Total Environ. 397 (2008) 31-40. 
[8] B. Kasprzyk-Hordern, R.M. Dinsdale, A.J. Guwy, The removal of pharmaceuticals, personal care products, endocrine disruptors and illicit drugs during wastewater treatment and its impact on the quality of receiving waters, Water Res. 43 (2009) 363-380.

[9] J.D. Berset, R. Brenneisen, C. Mathieu, Analysis of llicit and illicit drugs in waste, surface and lake water samples using large volume direct injection high performance liquid chromatography electrospray tandem mass spectrometry (HPLC-MS/MS), Chemosphere 81 (2010) 859-866.

[10] A.L.N. Van Nuijs, B. Pecceu, L. Theunis, N. Dubois, C. Charlier, P.G. Jorens, L. Bervoets, R. Blust, H. Neels, A. Covaci, Cocaine and metabolites in waste and surface water across Belgium, Environ. Pollut. 157 (2009) 123-129.

[11] E. Zuccato, S. Castiglioni, R. Bagnati, C. Chiabrando, P. Grassi, R. Fanelli, Illicit drugs, a novel group of environmental contaminants, Water Res. 42 (2008) 961-968.

[12] R. Álvarez-Ruiz, M.J. Andrés-Costa, V. Andreu, Y. Picó, Simultaneous determination of traditional and emerging illicit drugsin sediments, sludges and particulate matter, J. Chromatogr. A 1405 (2015) 103-115.

[13] M. Parolini, S. Magni, S. Castiglioni, A. Binelli, Genotoxic effects induced by the exposure to an environmental mixture of illicit drugs to the zebra mussel, Ecotoxicology and Environmental Safety 132 (2016) 26-30.

[14] M. Parolini, A. Pedriali, C. Riva, A. Binelli, Sub-lethal effects caused by the cocaine metabolite benzoylecgonine to the freshwater mussel Dreissena polymorpha, Sci. Total Environ. $444(2013) 43-50$.

[15] A. Pedriali, C. Riva, M. Parolini, S. Cristoni, D. Sheehan, A. Binelli, A redox proteomic investigation of oxidative stress caused by benzoylecgonine in the freshwater bivalve Dreissena polymorpha, Drug Test. Anal. 5 (2013) 646-656.

[16] A. Binelli, I. Marisa, M. Fedorova, R. Hoffmann, C. Riva, First evidence of protein profile alteration due to main cocaine metabolite (benzoylecgonine) in a freshwater biological model, Aquat. Toxicol. 140-141 (2013) 268-278. 
[17] J.P. García-Cambero, H. García-Cortés, Y. Valcárcel, M. Catalá, Environmental concentrations of the cocaine metabolite benzoylecgonine induced sublethal toxicity in the development of plants but not in a zebrafish embryo-larval model, J. Hazard. Mater. 300 (2015) 866-872.

[18] G. Orona, C. Campos, L. Gillerman, M. Salgot, Wastewater treatment, renovation and reuse for agricultural irrigation in small communities, Agric. Water Manage. 38 (3) (1999) 223-234.

[19] D. Christova-Boal, R.E. Eden, S. McFarlane, An investigation into greywater reuse for urban residential properties, Desalination 106(1-3) (1996) 391-397.

[20] G.Grissop, Orange county water district groundwater replenishment system, Journal of the New England Water Works Association 123(3) (2009) 230-237.

[21] D. Russo, D. Spasiano, M. Vaccaro, R. Andreozzi, G. Li Puma, N.M. Reis, R. Marotta, Direct photolysis of benzoylecgonine under UV irradiation at $254 \mathrm{~nm}$ in a continuous flow microcapillary film (MCF) array photoreactor, Chem. Eng. J. 283 (2016) 243-250.

[22] D. Russo, D. Spasiano, V. Vaccaro, K.H. Cochran, S.D. Richardson, R. Andreozzi, G. Li Puma, N.M. Reis, R. Marotta, Investigation on the removal of the major cocaine metabolite (benzoylecgonine) in water by $\mathrm{UV}_{254} / \mathrm{H}_{2} \mathrm{O}_{2}$, process by using a flow microcapillary film array photoreactor as an efficient experimental tool, Water Res. 89 (2016) 375-383.

[23] T. Mackulak, L. Birošová, I. Bodík, R. Grabic, A. Takáčová, M. Smolinská, A. Hanusová, J. Híveš, M. Gál, Zerovalent iron and iron(VI): Effective means for the removal of psychoactive pharmaceuticals and illicit drugs from wastewaters, Sci. Total Environ. 539 (2016) 420-426.

[24] J. Moreno-Andrés, L. Romero-Martínez, A. Acevedo-Merino, E. Nebot, Determining disinfection efficiency on $\mathrm{E}$. faecalis in saltwater by photolysis of $\mathrm{H}_{2} \mathrm{O}_{2}$ : Implications for ballast water treatment, Chem. Eng. J. 283 (2016) 1339-1348.

[25] B.S. Souza, R.F. Dantas, M. Agullo-Barcelò, F. Lucena, C. Sans, S. Esplugasa, M. Dezotti, Evaluation of $\mathrm{UV} / \mathrm{H}_{2} \mathrm{O}_{2}$ for the disinfection and treatment of municipal secondary effluents for water reuse, J. Chem. Technol. Biotechnol. 88 (2013) 1697-1706. 
[26] D. Rubio, E. Nebot, J.F. Casanueva, C. Pulgarin, Comparative effect of simulated solar light, $\mathrm{UV}, \mathrm{UV} / \mathrm{H}_{2} \mathrm{O}_{2}$ and photo-Fenton treatment (UV-Vis $/ \mathrm{H}_{2} \mathrm{O}_{2} / \mathrm{Fe}^{2+, 3+}$ ) in the Escherichia coli inactivation in artificial seawater, Water Res. 47 (2013) 6367-6379.

[27] J.C. Kruithof, P.C. Kamp, B.J. Martijn, UV/ $\mathrm{H}_{2} \mathrm{O}_{2}$ Treatment: A Practical Solution for Organic Contaminant Control and Primary Disinfection, Ozone Sci. Eng. 29 (2007) 273-280.

[28] U. Alkan, A. Teksoy, A. Atesli, H.S. Baskaya, Efficiency of the $\mathrm{UV} / \mathrm{H}_{2} \mathrm{O}_{2}$ process for the disinfection of humic surface waters, J. Environ. Sci. Health., Part A 42 (2007) 497-506.

[29] A. Lopez, A. Bozzi, G. Mascolo, J. Kiwi, Kinetic investigation on UV and $\mathrm{UV} / \mathrm{H}_{2} \mathrm{O}_{2}$ degradations of pharmaceutical intermediates in aqueous solution, J. Photochem. Photobiol., A $156(1-3)(2003) 121-126$.

[30] D. Vonga, R. Marotta, A. Napolitano, R. Andreozzi, M. d'lschia, Advanced oxidation of the pharmaceutical drug diclofenac with $\mathrm{UV} / \mathrm{H}_{2} \mathrm{O}_{2}$ and ozone, Water Res. 38(2) (2004) 414-422.

[31] V.J. Pereira, K.G. Linden, H.S. Weinberg, Evaluation of UV irradiation for photolytic and oxidative degradation of pharmaceutical compounds in water. Water Res., 41(19) (2007) 44134423.

[32] R. Andreozzi, V. Caprio, A. Insola, R. Marotta, Advanced oxidation processes (AOP) for water purification and recovery, Catal. Today 53(1) (1999) 51-59.

[33] G.V. Buxton, C.L. Greenstock, W.P. Helman, A.B. Ross, Critical review of rate constants for reactions of hydrated electrons, hydrogen atoms and hydroxyl radicals $(\mathrm{OH} / \mathrm{O})$ in aqueous solution, J. Phys. Chem. Ref. Data, 17 (1988) 513-886.

[34] P. Onstein, M.I Stefan, J.R. Bolton, Competition kinetics method for the determination of rate constants for the reaction of hydroxyl radicals with organic pollutants using the $\mathrm{UV} / \mathrm{H}_{2} \mathrm{O}_{2}$ advanced oxidation technology: the rate constants for the tert-buthyl formate ester and 2,4-dinitrophenol, J. Adv. Oxid. Technol. 4(2) (1999) 231-236.

[35] B.I Escher, K. Fenner, Recent advances in environmental risk assessment of transformation products, Environ. Sci. Technol. 45 (2011) 3835 - 3847. 
[36] C. Postigo, C. Sirtori, I. Ollerb, S. Malatob, M. I. Maldonado, M. L. de Aldaa, D. Barceló, Solar transformation and photocatalytic treatment of cocaine in water: Kinetics, characterization of major intermediate products and toxicity evaluation, Applied Catalysis B: Environmental 104 (2011) 37-48.

[37] T. An, J. An, Y. Gao, G. Li, H. Fanga, W. Song, Photocatalytic degradation and mineralization mechanism and toxicity assessment of antivirus drug acyclovir: Experimental and theoretical studies, Applied Catalysis B: Environmental 164 (2015) 279-287

[38] J. Xu, Z. Hao, C. Guo, Y. Zhang, Y. He, W. Meng, Photodegradation of sulfapyridine under simulated sunlight irradiation: Kinetics, mechanism and toxicity evolvement, Chemosphere 99 (2014) 186-191

[39] Organisation for Economic Cooperation and development (OECD), Guidelines for testing of Chemicals, Simulation Test-Aerobic Sewage Treatment, 1999, 303A.

[40] N.M. Reis, G. Li Puma, A novel microfluidic approach for extremely fast and efficient photochemical transformations in fluoropolymer microcapillary films, Chem. Commun. 51 (2015) 8414-8417.

[41] I. Nicole, J. De Laat, M. Doré, J.P. Duguet, C. Bonnel, Use of UV radiation in water treatment: measurement of photonic flux by hydrogen peroxide actinometry, Water Res. 24 (1990) 157-168.

[42] S. Goldstein, D. Aschengrau, Y. Diamant, J. Rabani, Photolysis of aqueous $\mathrm{H}_{2} \mathrm{O}_{2}$ : quantum yield and applications for polychromatic UV actinometry in photoreactors, Environ. Sci. Technol. 41 (2007) 7486-7490.

[43] K. Ura, T. Kai, S. Sakata, T. Iguchi, K. Arizono, Aquatic acute toxicity testing using the nematode Caenorhabditis elagans, J. Health Sci. 48 (2002) 583-586.

[44] P.L. Williams, D.B. Dusenbery, A promising indicator of neurobehavioral toxicity using the nematode Caenorhabditis elegans and computer tracking, Toxicol. Ind. Health 6 (1990) 425-440.

[45] G. Persoone, R. Baudo, M. Cotman, C. Blaise, K.C. Thompson, M. Moreira-Santos, B. Vollat, A. Törökne, T. Han, Review on the acute Daphnia magna toxicity test - Evaluation of the 
sensitivity and the precision of assays performed with organisms from laboratory cultures or hatched from dormant eggs, Knowl. Managt. Aquatic Ecosyst. 393 (2009) 01.

[46] A. Siciliano, R. Gesuele, G. Pagano, M. Guida, How Daphnia (Cladocera) Assays may be used as Bioindicators of Health Effects? J. Biodivers. Endanger Species S1 (2015) 005.

[47] I. Blinova, Use of freshwater algae and duckweeds for phytotoxicity testing, Environ. Toxicol. 19 (2004) 425-428.

[48] M. Iqbal, Vicia faba bioassay for environmental toxicity monitoring: A review. Chemosphere 144 (2016) 785-802.

[49] International Organization for Standardization (ISO) 8692, Water quality - Freshwater algal growth inhibition test with unicellular green algae (2012).

[50] International Organization for Standardization (ISO) 6341, Water quality - Determination of the inhibition of the mobility of Daphnia magna Straus (Cladocera, Crustacea) - Acute toxicity test (2012).

[51] Organisation for Economic Cooperation and development (OECD), Guidelines for the Testing of Chemicals, Section 2, 2008, 202.

[52] S.G. Donkin, P.L. Williams, Influence of developmental stage, salts and food presence on various end points using Caenorhabditis elegans for aquatic toxicity testing, Environ. Toxicol. Chem. 14 (1995) 2139-2147.

[53] T.H. Ma, Vicia faba cytogenetic test for environmental mutagen. A report of the U.S. Environmental Protection Agency Gene-Tox Program, Mutation Research 99 (1982) 257-271.

[54] J. Alexander, K.S. Mccarty, E. Alexanderjackson, Rapid method of preparing Schiff reagent for the Feulgen test, Science 111 (1950) 13-13.

[55] C.W. Dunnett, A multiple comparison procedure for comparing several treatments with a control, J. Amer. Statist. Assoc. 50 (1955) 1096-1121.

[56] J. W. Tukey, Comparing individual means in the analysis of variance, Biometrics 5 (1949) 99114. 
[57] B.H. Bielski, D.E. Cabelli, R.L. Aruda, A.B. Ross, Reactivity of $\mathrm{HO}_{2} / \mathrm{O}_{2}$ radicals in aqueous solution, J. Phys. Chem. Ref. Data 14 (1985) 1041-1077.

[58] J. De Laat, P. Berger, T. Poinot, N.K. Vel Leitner, M. Dorè, Proceedings of the 12th Ozone World Congress of the International Ozone Association, Lille, May 1995, 373.

[59] J. Schmidhuber, Deep learning in neural networks: An overview, Neural Networks 61 (2015) 85-117.

[60] B.A. Wols, C.H.M. Hofman-Caris, Review of photochemical reaction constants of organic micropollutants required for UV advanced oxidation processes in water, Water Res. 46 (2012) 2815-2827.

[61] B. Sosak-Swiderska, D. Tyrawska, D. Dzido, Daphnia magna ecotoxicity test with parathion, Chemosphere 37(14) (1998) 2989-3000.

[62] M.C. Artal, R.D. Holtz, F. Kummrow, O.L. Alves, G. de A. Umbuzeiro, The role of silver and vanadium release in the toxicity of silver vanadate nanowires toward Daphnia similis, Environ. Toxicol. Chem. 32 (2013) 908-912.

[63] S. Asghari, S.A. Johari, J.H. Lee, Y.S. Kim, Y.B. Jeon, H.J. Choi, M.C. Moon, I.J. Yu, Toxicity of various silver nanoparticles compared to silver ions in Daphnia magna, J. Nanobiotechnology 10 (2012) 14.

[64] V.A. Lakhnova, Influence of aniline on Daphnia magna Straus, Freshwater Biological Association, Windermere, UK, 1982.

[65] K.D. Kearns, M.D. Hunter, Green algal extracellular products regulate antialgal toxin production in a cyanobacterium, Environ. Microbiol. 2 (2000) 291-297.

[66] J.S. Metcalf, G.A. Codd, Cyanobacteria, neurotoxins and water resources: Are there implications for human neurodegenerative disease? Amyotroph. Lateral Scler. 10(s2) (2009) 74-78. [67] M. Artal-Sanz, L. de Jong, N. Tavernarakis, C. elegans: A versatile platform for drug discovery, Biotechnol. J. 1 (2006) 1405-1418. 
[68] L. Ségalat, Invertebrate animal models of diseases as screening tools in drug discovery, ACS Chem. Bio. 2 (2007) 231-236.

[69] P.L. Williams, D.B. Dusenbery, Aquatic toxicity testing using the nematode, Caenorhabditis elegans, Environ. Toxicol. Chem. 9 (1990) 1285-1290.

[70] E.E. Kenaga, Predictability of chronic toxicity from acute toxicity of chemicals in fish and aquatic invertebrates, Environ. Toxicol. Chem. 1 (1982) 347-358. 


\begin{tabular}{c|ccc|} 
& Run 1 & Run 2 & Run 3 \\
\hline$\left[\mathrm{H}_{2} \mathrm{O}_{2}\right]_{0}\left(10^{-3} \mathrm{M}\right)$ & 17.9 & 6.4 & 2.3 \\
$\mathrm{k}_{\mathrm{OH} / \mathrm{BE}}\left(10^{-9} \mathrm{M}^{-1} \cdot \mathrm{s}^{-1}\right)$ & 5.37 & 5.17 & 4.85 \\
$\mathrm{R}^{2}$ & 0.9998 & 0.9975 & 0.9971 \\
\hline
\end{tabular}

Table 1 


\begin{tabular}{ccc}
\hline $\left.\mathrm{r}_{1}\right)$ & $\mathrm{BE} \stackrel{\mathrm{h} v}{\longrightarrow} \mathrm{BPs}$ & $\begin{array}{c}\Phi_{254}^{\mathrm{BE}}=6.22 \cdot 10^{-3} \mathrm{~mol} \cdot \mathrm{ein}^{-1} \\
\varepsilon_{254}^{\mathrm{BE}}=1684 \mathrm{M}^{-1} \cdot \mathrm{cm}^{-1}\end{array}$ \\
$\left.\mathrm{r}_{2}\right)$ & $\mathrm{H}_{2} \mathrm{O}_{2} \stackrel{\mathrm{h} v}{\longrightarrow} 2 \mathrm{HO}$ & $\Phi_{254}^{\mathrm{H}_{2} \mathrm{O}_{2}}=0.55 \mathrm{~mol} \cdot \mathrm{ein}^{-1}$ \\
$\varepsilon_{254}^{\mathrm{H}_{2} \mathrm{O}_{2}}=18.6 \mathrm{M}^{-1} \cdot \mathrm{cm}^{-1}$
\end{tabular}

Table 2 


\begin{tabular}{cccccc}
\hline Run & $\begin{array}{c}{[\mathrm{BE}]_{0}} \\
(\mathrm{M})\end{array}$ & $\begin{array}{c}{\left[\mathrm{H}_{2} \mathrm{O}_{2}\right]_{0}} \\
(\mathrm{M})\end{array}$ & $\begin{array}{c}\mathrm{I}_{0 / \mathrm{MCF}} / \mathrm{V}_{\mathrm{MCF}} \\
\left(\mathrm{ein} \cdot \mathrm{s}^{-1} \cdot \mathrm{L}^{-1}\right)\end{array}$ & $\begin{array}{c}\sigma_{\mathrm{BE}} \\
(\%)\end{array}$ & $\begin{array}{c}\sigma_{\mathrm{H}_{2} \mathrm{O}_{2}} \\
(\%)\end{array}$ \\
\hline 1 & $6.39 \cdot 10^{-5}$ & $5.03 \cdot 10^{-3}$ & & 1.35 & 0.08 \\
2 & $2.52 \cdot 10^{-5}$ & $1.04 \cdot 10^{-3}$ & & 0.92 & 0.69 \\
3 & $2.87 \cdot 10^{-5}$ & $0.42 \cdot 10^{-3}$ & & 1.01 & 0.61 \\
4 & $2.62 \cdot 10^{-5}$ & $5.00 \cdot 10^{-3}$ & $1.92 \cdot 10^{-2}$ & 0.39 & 0.31 \\
5 & $3.35 \cdot 10^{-5}$ & $10.4 \cdot 10^{-3}$ & & 0.16 & 0.13 \\
6 & $2.98 \cdot 10^{-5}$ & $20.4 \cdot 10^{-3}$ & & 1.41 & 0.18 \\
\hline $1 \mathrm{~s}$ & $2.82 \cdot 10^{-5}$ & $0.42 \cdot 10^{-3}$ & & 0.56 & 0.52 \\
$2 \mathrm{~s}$ & $2.82 \cdot 10^{-5}$ & $1.10 \cdot 10^{-3}$ & & 0.45 & 0.21 \\
$3 \mathrm{~s}$ & $2.84 \cdot 10^{-5}$ & $2.31 \cdot 10^{-3}$ & & & 0.77 \\
$4 \mathrm{~s}$ & $2.35 \cdot 10^{-5}$ & $5.05 \cdot 10^{-3}$ & & 1.06 & 0.19 \\
\hline
\end{tabular}

Table 3 


\begin{tabular}{cccccc}
\hline Run & Matrix & $\begin{array}{c}{[\mathrm{BE}]_{0}} \\
(\mathrm{M})\end{array}$ & $\begin{array}{c}{\left[\mathrm{H}_{2} \mathrm{O}_{2}\right]_{0}} \\
(\mathrm{M})\end{array}$ & $\begin{array}{c}\sigma_{\mathrm{BE}} \\
(\%)\end{array}$ & $\begin{array}{c}\sigma_{\mathrm{H}_{2} \mathrm{O}_{2}} \\
(\%)\end{array}$ \\
\hline 1 & SWW & $2.1 \cdot 10^{-6}$ & $5.0 \cdot 10^{-4}$ & 0.37 & 0.37 \\
2 & SWW & $3.26 \cdot 10^{-5}$ & $7.4 \cdot 10^{-3}$ & 0.48 & 0.17 \\
3 & SWW & $3.08 \cdot 10^{-5}$ & $5.0 \cdot 10^{-3}$ & 0.71 & 0.40 \\
4 & SurW & $2.80 \cdot 10^{-5}$ & $1.4 \cdot 10^{-3}$ & 0.49 & 0.52 \\
5 & SurW & $2.88 \cdot 10^{-5}$ & $6.7 \cdot 10^{-3}$ & 0.15 & 0.43 \\
\hline $1 \mathrm{~s}$ & SWW & $3.08 \cdot 10^{-5}$ & $1.5 \cdot 10^{-3}$ & 0.59 & 0.98 \\
$2 \mathrm{~s}$ & $\mathrm{RWW}$ & $3.34 \cdot 10^{-5}$ & $7.6 \cdot 10^{-3}$ & 1.53 & 0.15 \\
$3 \mathrm{~s}$ & $\mathrm{RWW}$ & $3.36 \cdot 10^{-5}$ & $14.9 \cdot 10^{-3}$ & 1.82 & 0.22 \\
$4 \mathrm{~s}$ & $\mathrm{RWW}$ & $3.37 \cdot 10^{-5}$ & $21.9 \cdot 10^{-3}$ & 0.55 & 0.24 \\
$5 \mathrm{~s}$ & SurW & $3.21 \cdot 10^{-5}$ & $13.1 \cdot 10^{-3}$ & 0.56 & 0.16 \\
$6 \mathrm{~s}$ & SurW & $3.05 \cdot 10^{-5}$ & $19.2 \cdot 10^{-3}$ & 0.65 & 0.15 \\
\hline
\end{tabular}

Table 4 


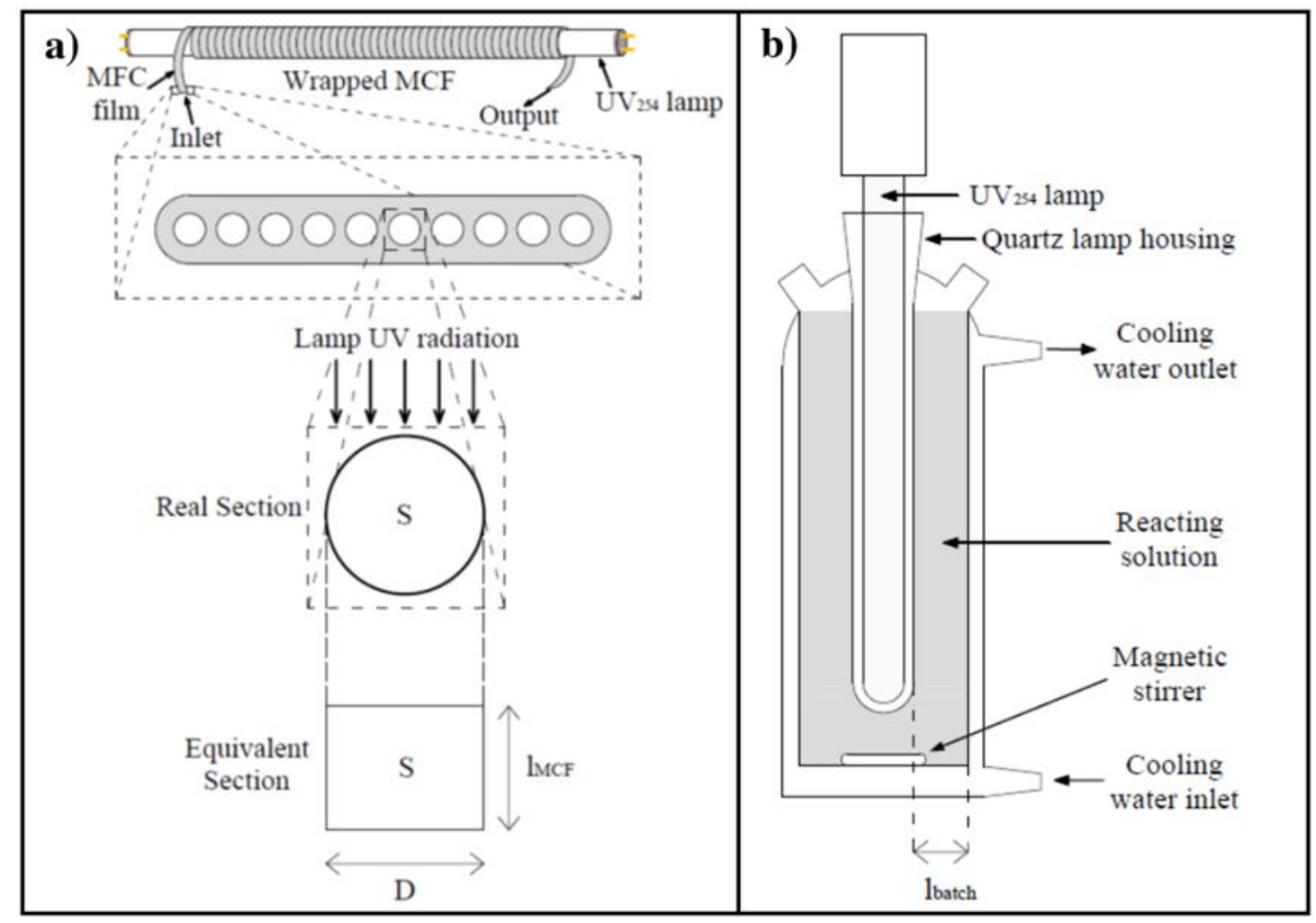

Figure 1 


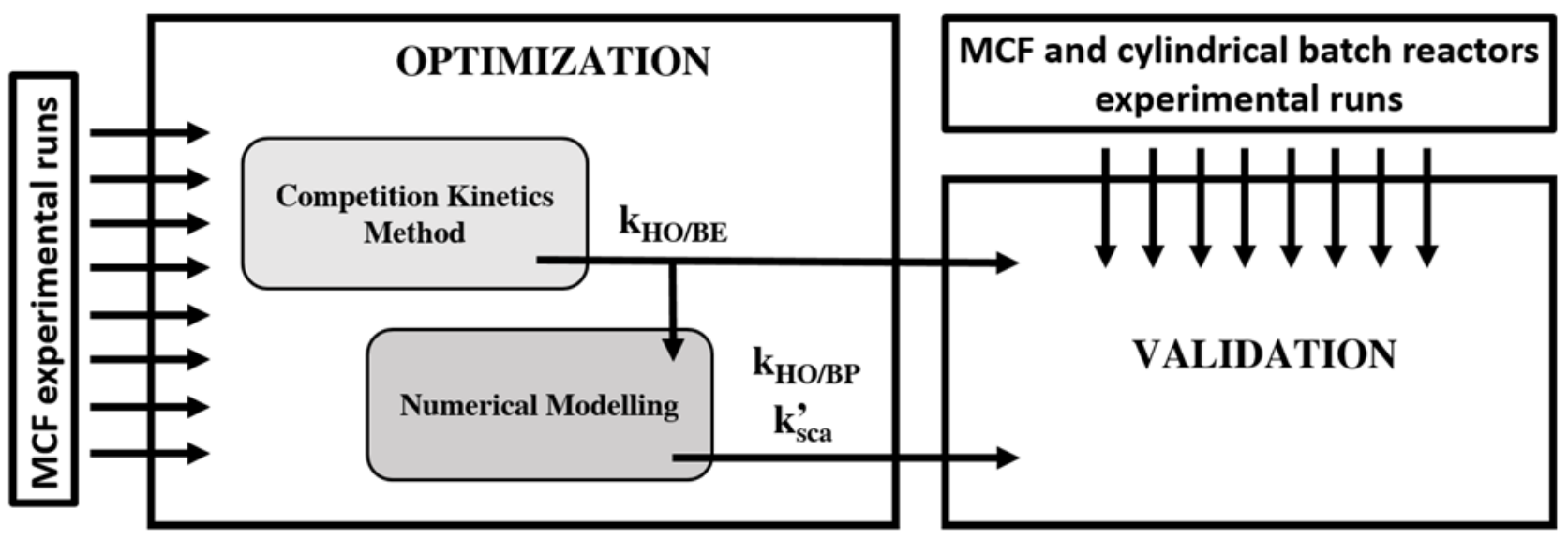

Figure 2 

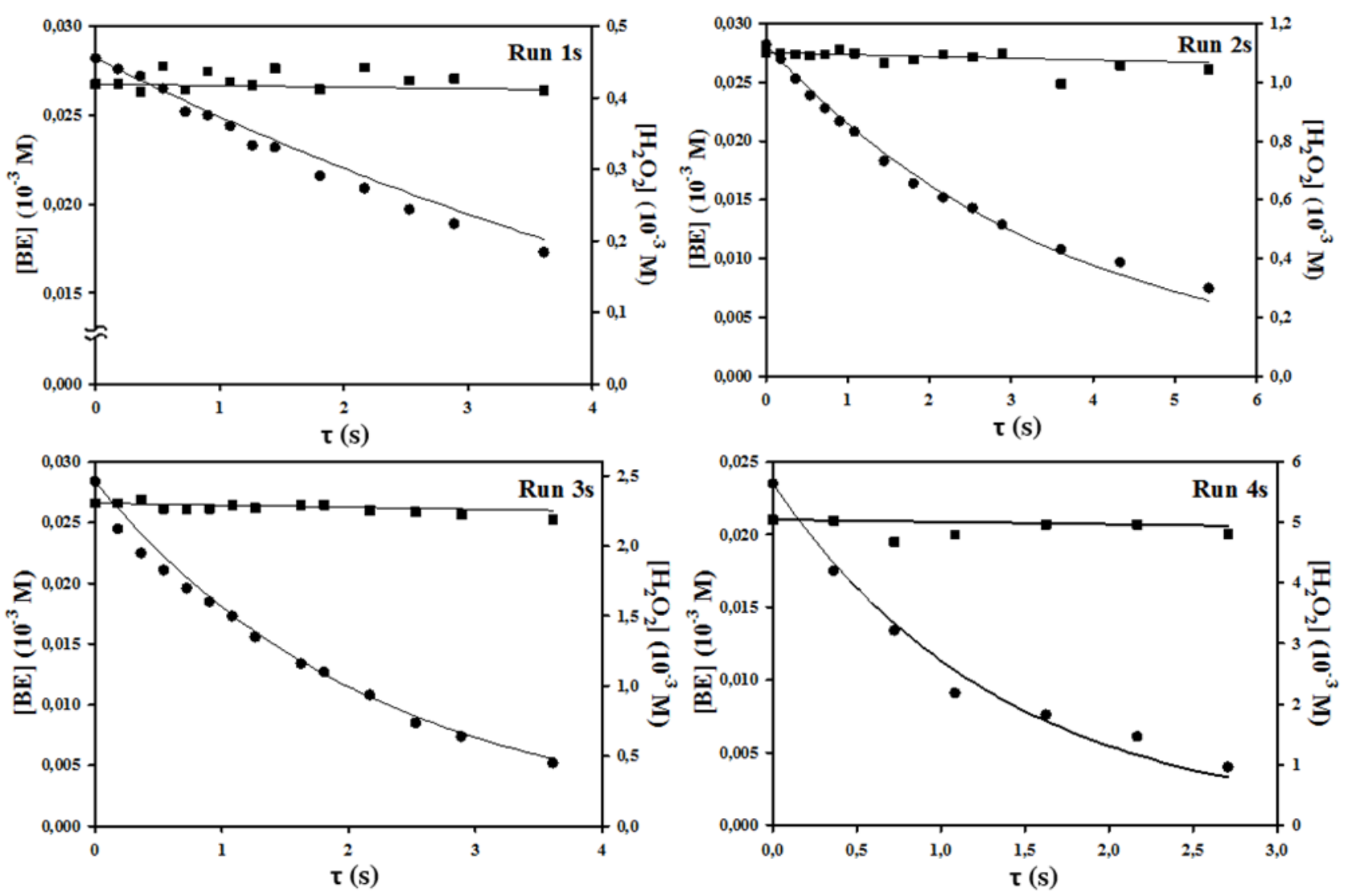

Figure 3 


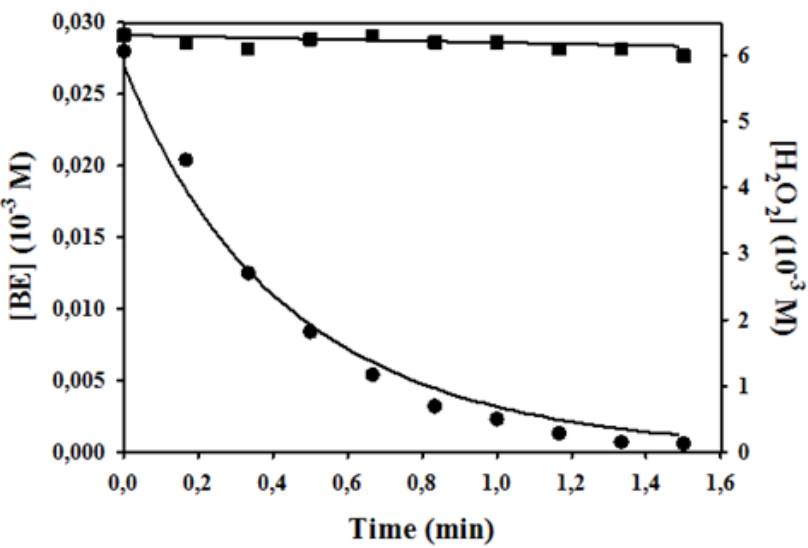

Figure 4 

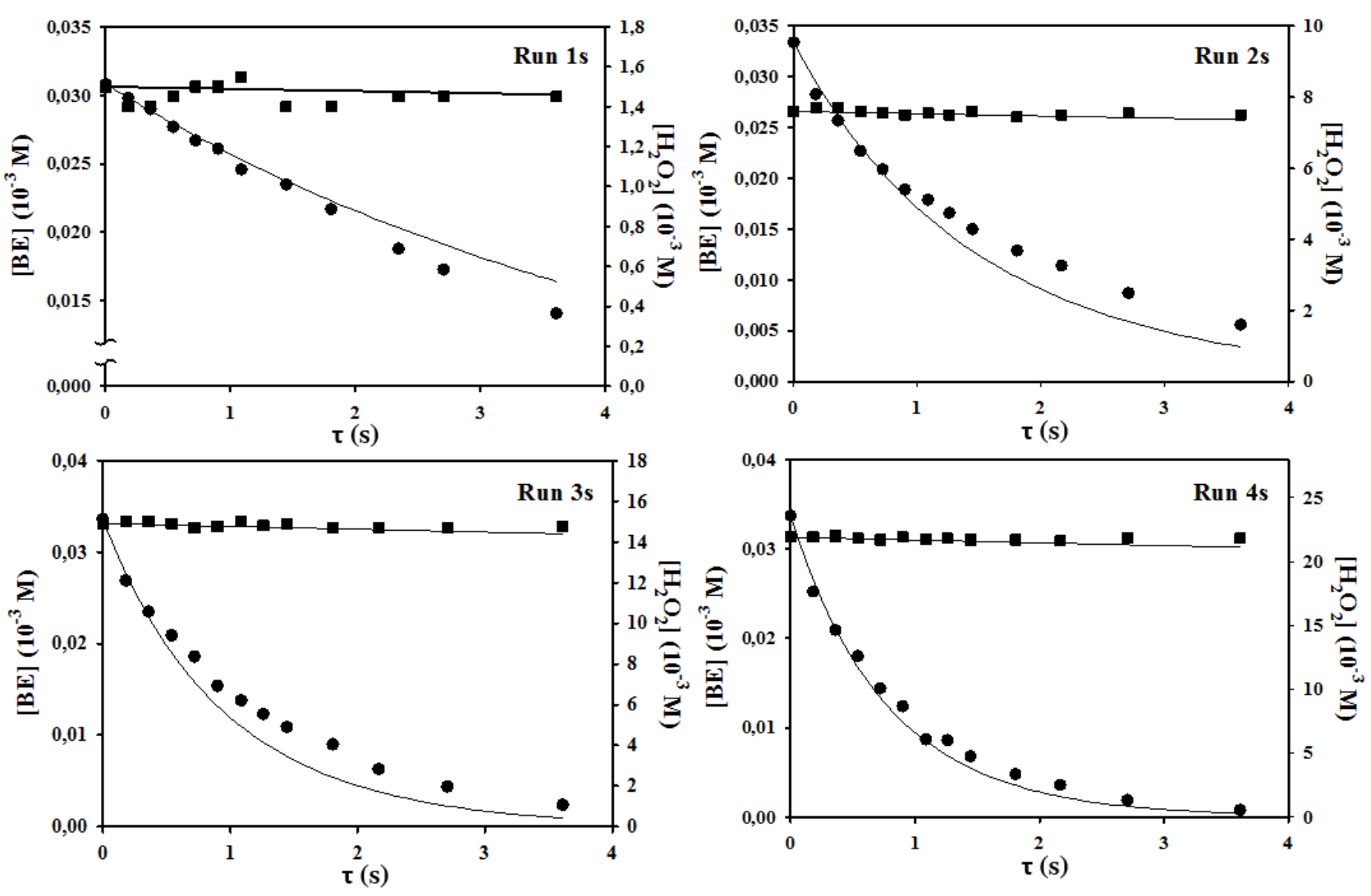

Figure 5 


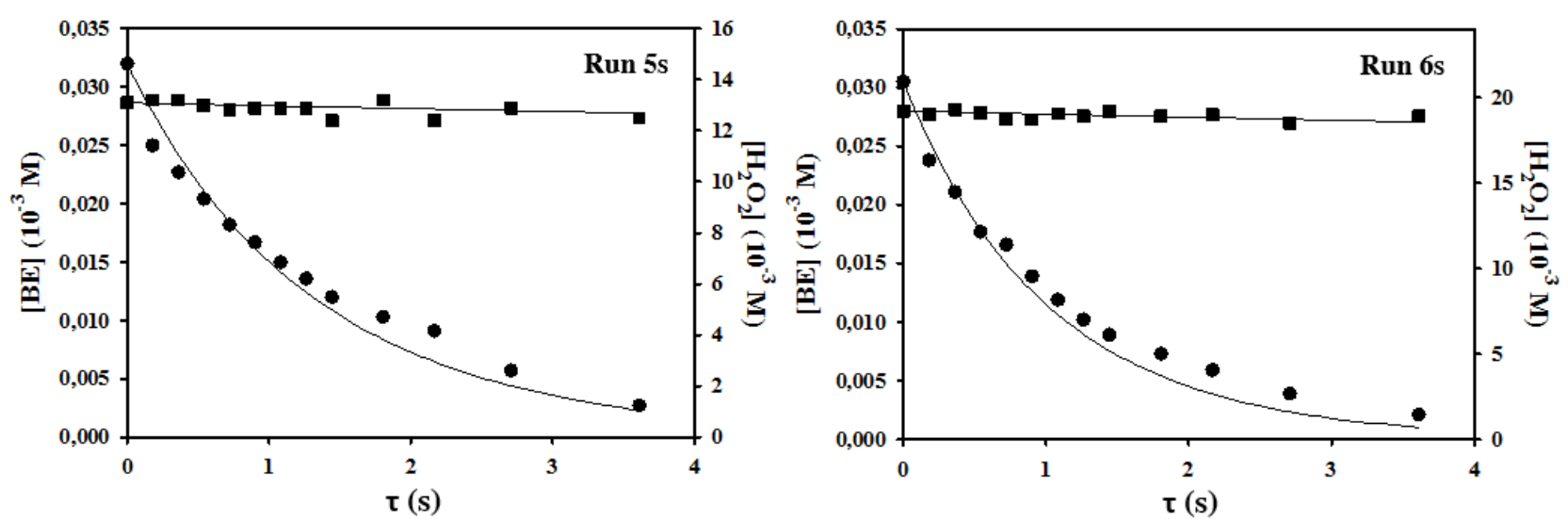

Figure 6 


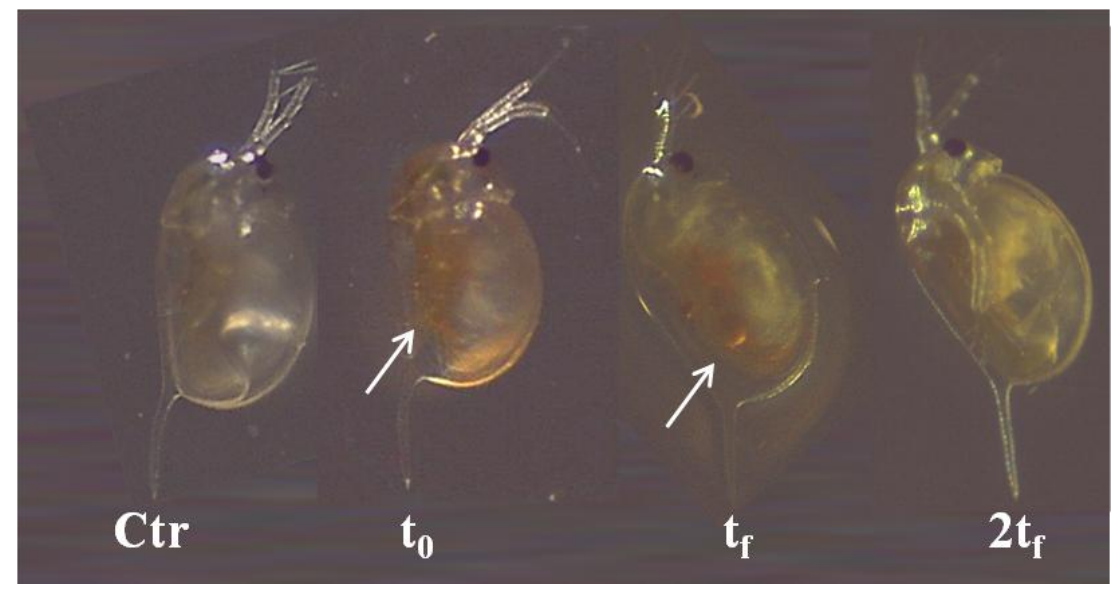

Figure 7 


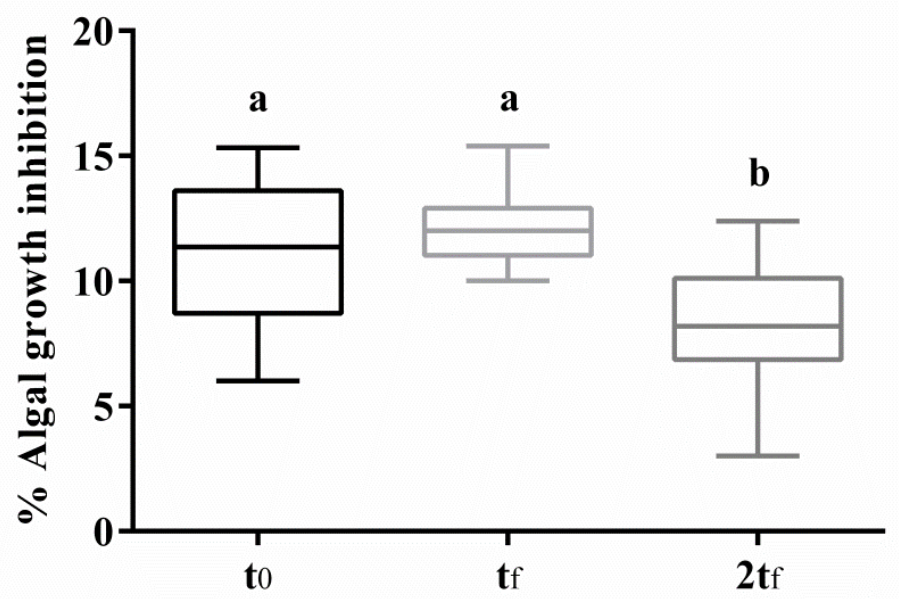

Figure 8 

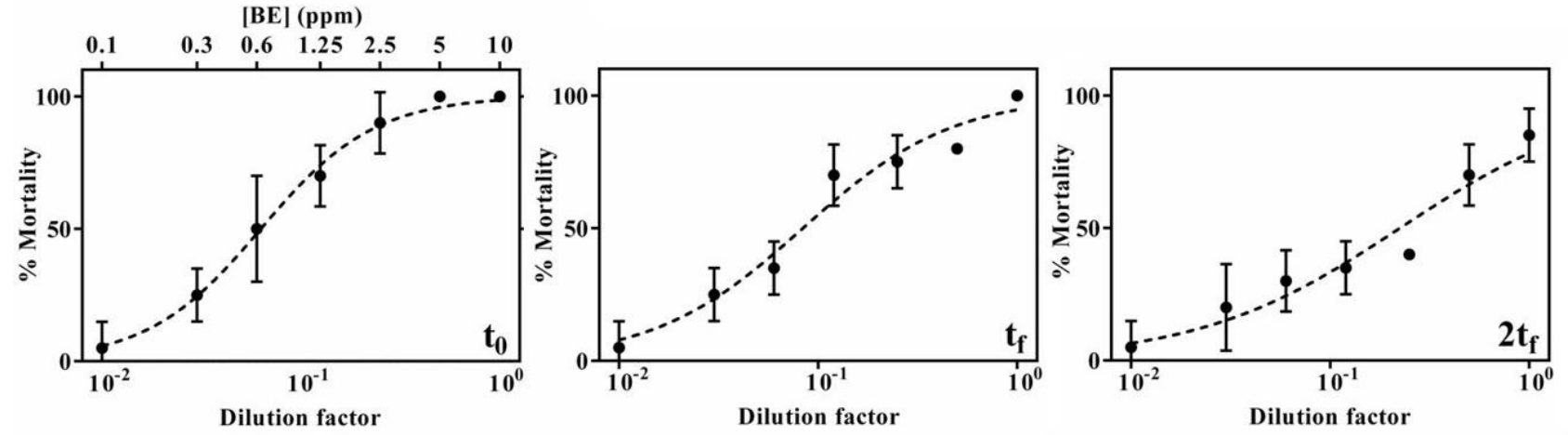

Figure 9 


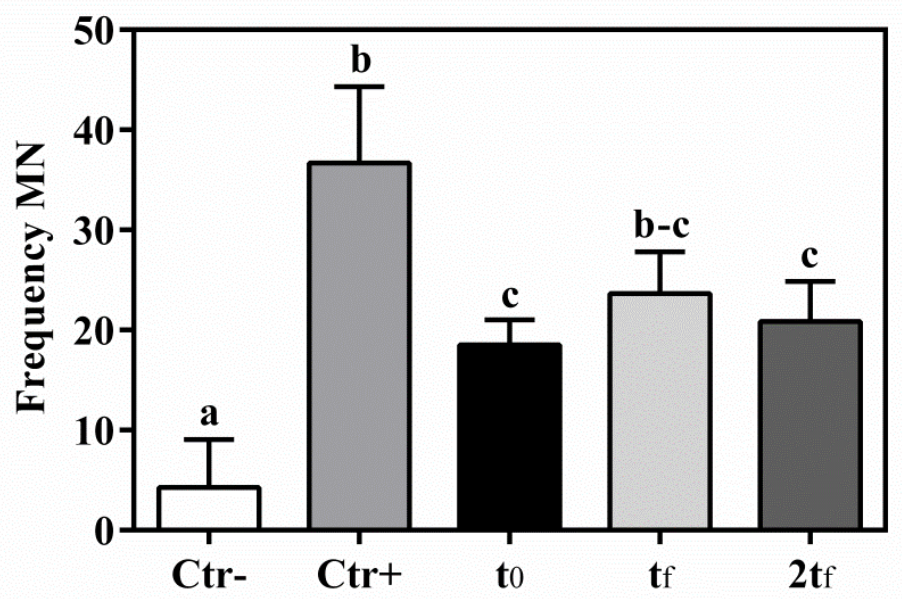

Figure 10 
Fig. 1. MCF photoreactor (a) and cylindrical batch photoreactor (b).

Fig. 2. Optimization and validation procedures scheme.

Fig. 3. $\mathrm{UV}_{254} / \mathrm{H}_{2} \mathrm{O}_{2}$ removal of $\mathrm{BE}$ from milli-Q water in the $\mathrm{MCF}$ at different space times. Predicted (continuous lines) and experimental (symbols). (•) $[\mathrm{BE}],(\boldsymbol{\bullet})\left[\mathrm{H}_{2} \mathrm{O}_{2}\right] \cdot \mathrm{pH}=6.0 . \mathrm{T}=25^{\circ} \mathrm{C}$.

Fig. 4. $\mathrm{UV}_{254} / \mathrm{H}_{2} \mathrm{O}_{2}$ removal $\mathrm{BE}$ from milli-Q water in the cylindrical batch photoreactor. Predicted (continuous lines) and experimental (symbols). (•) $[\mathrm{BE}],(\boldsymbol{\bullet})\left[\mathrm{H}_{2} \mathrm{O}_{2}\right] .[\mathrm{BE}]_{0}=3.5 \cdot 10^{-5} \mathrm{M}$, $\left[\mathrm{H}_{2} \mathrm{O}_{2}\right]_{0}=6.3 \cdot 10^{-3} \mathrm{M} \cdot \mathrm{pH}=6.0 . \mathrm{T}=25^{\circ} \mathrm{C}$.

Fig. 5. $\mathrm{UV}_{254} / \mathrm{H}_{2} \mathrm{O}_{2}$ removal of $\mathrm{BE}$ from $\mathrm{SWW}$ (run 1s) and $\mathrm{RWW}$ (run 2s-4s) in the MCF at different space times. Predicted (continuous lines) and experimental (symbols). (•) [BE], (ロ) $\left[\mathrm{H}_{2} \mathrm{O}_{2}\right] \cdot \mathrm{I}_{0 / \mathrm{MCF}} / \mathrm{V}_{\mathrm{MCF}}=1.92 \cdot 10^{-2} \mathrm{ein} \cdot \mathrm{s}^{-1} \cdot \mathrm{L}^{-1} \cdot \mathrm{pH}_{\mathrm{SWW}}=6.0 \cdot \mathrm{pH}_{\mathrm{RWW}}=7.6 . \mathrm{T}=25^{\circ} \mathrm{C}$.

Fig. 6. $\mathrm{UV}_{254} / \mathrm{H}_{2} \mathrm{O}_{2}$ removal of $\mathrm{BE}$ from SurW in the MCF at different space times. Predicted (continuous lines) and experimental (symbols). (•) $[\mathrm{BE}],(\boldsymbol{\bullet})\left[\mathrm{H}_{2} \mathrm{O}_{2}\right] . \mathrm{I}_{0 / \mathrm{MCF}} / \mathrm{V}_{\mathrm{MCF}}=1.92 \cdot 10^{-2}$ ein $\cdot \mathrm{s}^{-}$ ${ }^{1} \cdot \mathrm{L}^{-1} \cdot \mathrm{pH}=7.8 \cdot \mathrm{T}=25^{\circ} \mathrm{C}$.

Fig. 7. D.magna exposed to BE samples treated at different reaction times. The arrows indicate the presence of lipid droplets in $t_{0}$ and $t_{\mathrm{f}}$ samples.

Fig. 8. Growth inhibition of algae $R$. subcapitata exposed to BE samples treated at different reaction times. Data with different letters ( $a$ and $b)$ are significantly different $(p<0.05)$.

Fig. 9. Dose-response curve describing the inhibitory effects of $\mathrm{BE}$ and its $\mathrm{UV}_{254} / \mathrm{H}_{2} \mathrm{O}_{2}$ by-products on survival of C. elegans.

Fig. 10. Mean micronucleus (MN) frequencies (expressed per 1000 cells) detected in $V$. faba root tip cells after exposure to BE samples treated at different reaction times. Data with different letters (a-c) are significantly different $(\mathrm{p}<0.05)$.

Table 1 Competition kinetics results. $[\mathrm{BE}]_{0}=4 \cdot 10^{-5} \mathrm{M} .[\mathrm{BA}]_{0}=1.0 \cdot 10^{-4} \mathrm{M} . \mathrm{pH}=6.0 . \mathrm{T}=25^{\circ} \mathrm{C}$.

Table 2 Simplified reaction kinetics mechanism of BE oxidation by $\mathrm{UV}_{254} / \mathrm{H}_{2} \mathrm{O}_{2}$ process.

Table 3 Experimental conditions of the runs used for the optimization (runs 1-6) and validation (runs 1s-4s) procedures and the percentage standard deviations. 
Table 4 Experimental conditions of the runs used for the optimization (runs 1-5) and validation (runs 1s-6s) modes and percentage standard deviations. 


\section{Statement of novelty}

At the best of our knowledge, this is the first investigation about the evaluation of the kinetic constants of the reactions between hydroxyl radical, generated by the $\mathrm{UV}_{254} / \mathrm{H}_{2} \mathrm{O}_{2}$ advanced oxidation process, and benzoyecgonine and its by-products deriving from this process. Furthermore, this investigation was carried out by using an innovative microcapillary film array photoreactor as an effective experimental tool to study oxidative removal of highly priced, uncommon, or regulated substances. The submitted manuscript is also enriched by an ecotoxicity and a genotoxicity assessment of the benzoylecgonine contaminated water solutions before and, for the first time, after the proposed treatment. 